\title{
Hydrothermal eruption dynamics reflecting vertical variations in host rock geology and geothermal alteration, Champagne Pool, Wai-o-tapu, New Zealand
}

\author{
Anna Gallagher $^{1} \cdot$ Cristian Montanaro $^{1,2}$ (D) $\cdot$ Shane Cronin ${ }^{1} \cdot$ Bradley Scott $^{3} \cdot$ Donald B. Dingwell $^{2} \cdot$ Bettina Scheu $^{2}$
}

Received: 6 June 2020 / Accepted: 15 October 2020 / Published online: 14 November 2020

(C) The Author(s) 2020

\begin{abstract}
Hydrothermal eruptions are characterised by violent explosions ejecting steam, water, mud, and rock. They pose a risk to tourism and the operation of power plants in geothermal areas around the world. Large events with a severe destructive threat are often intensified by the injection of magmatic fluids along faults and fractures within volcanotectonic rifting environments, such as the Taupo Volcanic Zone. How these hydrothermal eruptions progress, how craters form and the scale of ejecta impacts, are all influenced by the local geology and reservoir hydrology. By analysing breccia lithology, undisturbed strata proximal to the explosion sites, and conducting tailored decompression experiments, we elucidate the eruption sequence that formed Champagne Pool, Wai-o-tapu, New Zealand. This iconic touristic site was formed by a violent hydrothermal eruption at $\sim 700$ years B.P. Samples from undisturbed drill cores and blocks ejected in the eruption were fragmented in shock-tube experiments under the moderate pressure/temperature conditions estimated for this system $\left(3-4 \mathrm{MPa}, 210-220{ }^{\circ} \mathrm{C}\right)$. Our results show that this was a two-phase eruption. It started with an initial narrow jetting of deep-sourced lithologies, ejecting fragments from at least a 110-m depth. This event was overtaken by a larger, broader, and dominantly shallower eruption driven by decompression of much more geothermal fluid within a soft and porous ignimbrite horizon. The second phase was triggered once the initial, deeper-sourced eruption broke through a strong silicified aquitard cap. The soft ignimbrite collapsed during the second-phase eruption into the crater, to repeatedly choke the explosions causing short-term pressure rises that triggered ongoing deeper-sourced eruptions. The eruption spread laterally also by exploiting a local fault. These results are relevant for hydrothermal eruption hazard scenarios in environments where strong vertical variations in rock strength and porosity occur.
\end{abstract}

Keywords Hydrothermal eruptions $\cdot$ Geothermal $\cdot$ Champagne pool $\cdot$ Experimental $\cdot$ Eruption dynamics

Editorial responsibility: G. Lube

Supplementary Information The online version contains supplementary material available at https://doi.org/10.1007/s00445-02001414-3.

Cristian Montanaro

cristian.montanaro@min.uni-muenchen.de

1 School of Environment, Science Centre, University of Auckland, Building 302, 23 Symonds Street, Auckland Central, New Zealand

2 Ludwig-Maximilians-Universität München, Theresienstrasse 41, 80333 Munich, Germany

3 GNS Science, 114 Karetoto Rd., Wairakei 3377, New Zealand

\section{Introduction}

Steam-driven hydrothermal eruptions commonly occur in both volcanic and geothermal systems (Stix and Moor 2018). The most deadly eruptions in recent times have been associated with vent-hosted hydrothermal systems on volcanoes, e.g. 2014 Ontake eruption, Japan (Yamamoto 2014) and 2019 Whakaari/White Island, New Zealand (Kennedy et al. 2020). Sites of intermittent volcanism in humid environments are highly prone to steam-driven eruptions (Kilgour et al. 2019; Jolly et al. 2020). Hydrothermal eruptions are also very common in other settings because they only require hot and pressurised geothermal fluid circulation (Browne and Lawless 2001). In these cases, rapid fluid decompression could be triggered by tectonic fault rupture, landslides and sudden 
hydrological (e.g. lake level) changes. Within active volcanotectonic rifts, such as that of the central North Island of New Zealand (Rowland and Simmons 2012; Wilson and Rowland 2016), failed dyke intrusions and magmatic fluids rising along fracture systems may drive especially violent hydrothermal eruptions in areas distant from volcanoes (Hedenquist and Henley 1985; Nairn et al. 2005; Montanaro et al. 2020).

Driven by flashing of superheated groundwater or geothermal fluids at shallow depths (Mastin 1995; Thiéry and Mercury 2009), hydrothermal eruptions violently eject fragmented host rock, caustic fluids, steam, and fine ash as ballistics and wet debris jets. They may also generate steamrich density currents (surges) of poorly sorted rock debris (Lube et al. 2014; Maeno et al. 2016; Kilgour et al. 2019). The wide diversity of rock types in geothermal areas causes a great variability in hydrothermal eruption dynamics (Browne and Lawless 2001; Montanaro et al. 2016, 2020). By examining the characteristic lithologies and particle properties within hydrothermal eruption deposits, the dynamics and sources of eruptions can be estimated (Breard et al. 2014; Mayer et al. 2015; Montanaro et al. 2016, 2020; Pittari et al. 2016; D’Elia et al. 2020). Valuable insights into the source rock properties come from analysing blocks within the hydrothermal breccias (Montanaro et al. 2016; Heap et al. 2017), or from rare shallow $(<400 \mathrm{~m})$ nearby drill cores. Wells also provide direct information on the hydrothermal system state (pressure, temperature) and rock properties such as porosity, permeability, and alteration state (Dobson et al. 2003; Mielke et al. 2015; Milicich et al. 2016, 2020; Carlino et al. 2018).

Here, we examine the large hydrothermal eruption that formed Champagne Pool, which is one of the main New Zealand geothermal tourist attractions in the Wai-o-tapu geothermal field (Fig. 1; Browne and Lawless 2001). We examined the Champagne Pool breccia and ejected particles (blocks and matrix) as well as samples from shallow drill cores adjacent to the explosion site. Adding laboratory decompression experiments, we explored the fragmentation and ejection behaviour of the variable substrate materials in order to reconstruct the evolution of the Champagne Pool hydrothermal eruption and determine the relationship between hydrothermal eruption properties and parent host rocks.

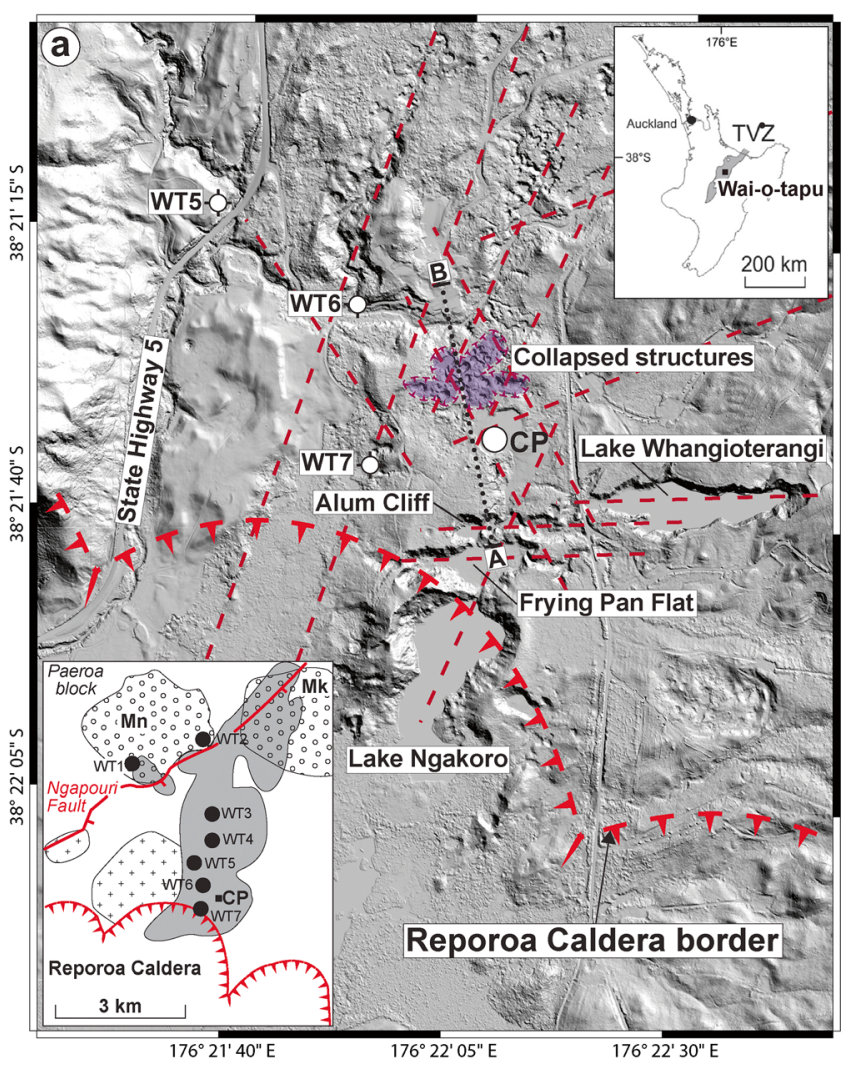

Fig. 1 Geological setting of southern Wai-o-tapu geothermal areas. a Lidar map (1 m resolution) with main structural and morphological features (from Lloyd 1959; Curewitz and Karson 1997; Rowland and Simmons 2012). Dashed red lines represent faults; the black dot line is the cross-section (A-B) for the geological profile shown in Fig. 2. Lidar data are sourced from the LINZ Data Service licenced for reuse under CC BY 4.0. The inset map shows the major geologic features and the

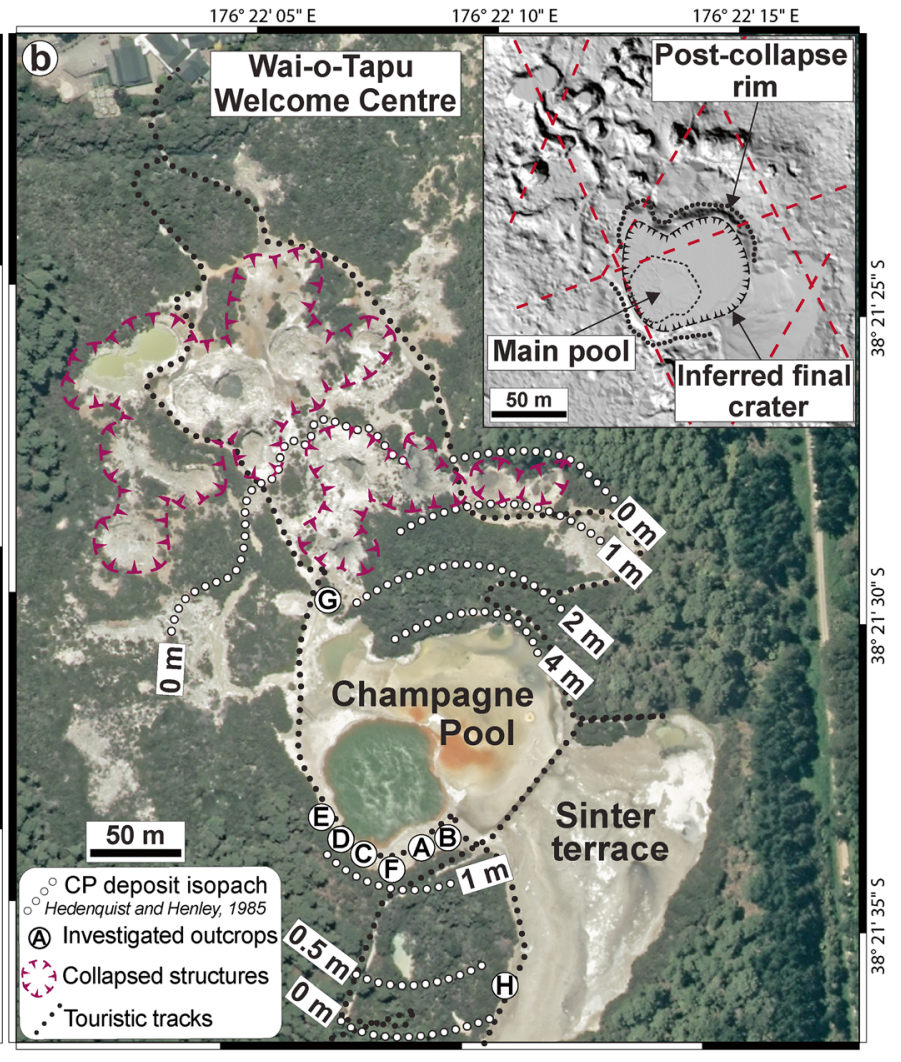

locations of the 1956-1958 drill core wells, as well as the extent of Wai-o-tapu surface thermal activity (shaded grey area). b Satellite image (Google Earth ${ }^{\mathrm{TM}}$, 2016) of Champagne Pool (CP) and surrounding areas; isopach of the breccia (from Hedenquist and Henley, 1985) are also reported, in the inset lidar map showing the faults (dashed red line), as well as the inferred final crater and the post-collapsed rim around Champagne Pool 


\section{Geological setting}

Wai-o-tapu (Fig. 1) is a geothermal area covering $10.5 \mathrm{~km}^{2}$, as delimited by its low resistivity anomaly (Bibby et al. 1994). It is known for its high heat flow and localised precipitation of gold and silver and is one of the most photographed natural features in New Zealand, Champagne Pool (Hedenquist and Henley 1985). Two dacite domes, Maungaongaonga and Maungakakaramea, bound the geothermal area in the north, whereas the upthrown, footwall of the faulted Paeroa block (> $600 \mathrm{~m}$ of normal offset) lies to the west (Fig. 1). In the south, Wai-o-tapu is dissected by ring faults associated with the northern margin of the Reporoa caldera (Nairn et al. 1994) which, along with the NE-striking Ngapouri fault, host numerous hydrothermal eruption vents (Hedenquist and Henley 1985; Nairn et al. 2005).

The subsurface hydrology has been deduced from seven drill holes (WT 1-7, Fig. 1) penetrating to depths of 500 to $1100 \mathrm{~m}$ and spring chemistry (Hedenquist and Browne 1989; Hedenquist 1991; Wilson et al. 2010). Deep fluids ascend along temperature and pressure gradients that are close to boiling in the vicinity of WT-6 and Champagne Pool (Fig. 2a). The latter is one of the more than twenty hydrothermal eruption vents in the Wai-o-tapu area, which are commonly located where regional or caldera faults cross the geothermal field (Fig. 1). The highest chloride concentration occurs in waters at Champagne Pool, indicating that it currently represents a highly permeable flow path that taps the deepest known water in the system (Hedenquist 1991). The stratigraphy in the Wai-o-tapu area comprises almost flat-lying felsic pyroclastic deposits and locally reworked derivatives of these, along with andesite and dacite lava flows, and fine-grained lacustrine sediments in varying states of lithification. The variations in texture and permeability form a series of stacked aquifers, capped by aquicludes (Hedenquist and Henley 1985; Wilson et al. 2010; Wilson and Rowland 2016). Volcanic rocks penetrated by the Wai-o-tapu wells show highly variable degrees of alteration and permeability (Hedenquist and Browne 1989). Primary mafic minerals are often completely replaced and plagioclase is usually completely altered to a mineral assemblage, including variable amounts of albite, adularia, calcite, mica, and/or epidote. The groundmass is generally re-crystallised, silicified, and pyritised. Below $150 \mathrm{~m}$ ( $200{ }^{\circ} \mathrm{C}$ on the boiling point-depth curve), the main alteration minerals in approximate order of decreasing abundance include quartz, white mica (mainly illite), albite, adularia, pyrite, calcite, epidote, wairakite, mordenite, and galena. Above this silicified zone at up to depths of $50 \mathrm{~m}$, surficial acid sulphate waters cause irregularly distributed advanced argillic alteration. The mineralogy here consists of kaolin, alunite, cristobalite, native sulphur, and fine pyrite (Hedenquist and Henley 1985).

\section{Champagne Pool eruption and local stratigraphy}

Champagne Pool, together with several other hydrothermal eruption vents in Wai-o-tapu, formed around 700 years B.P. The origin of these eruptions are linked to intrusion and arrest of magma, or related magmatic fluids within faults prior to the large rhyolitic effusive and explosive A.D. 1315 Kaharoa Plinian eruption sequence at Tarawera volcano, located < $20 \mathrm{~km}$ to the northeast (Nairn et al. 2005). The Champagne Pool eruption occurred soon after the explosive phase of the Kaharoa eruption (Nairn et al. 2005). Dykes intruding across the region surrounding Mount Tarawera were channelled by existing fault and fracture networks to inject $\mathrm{CO}_{2}$ (and or other

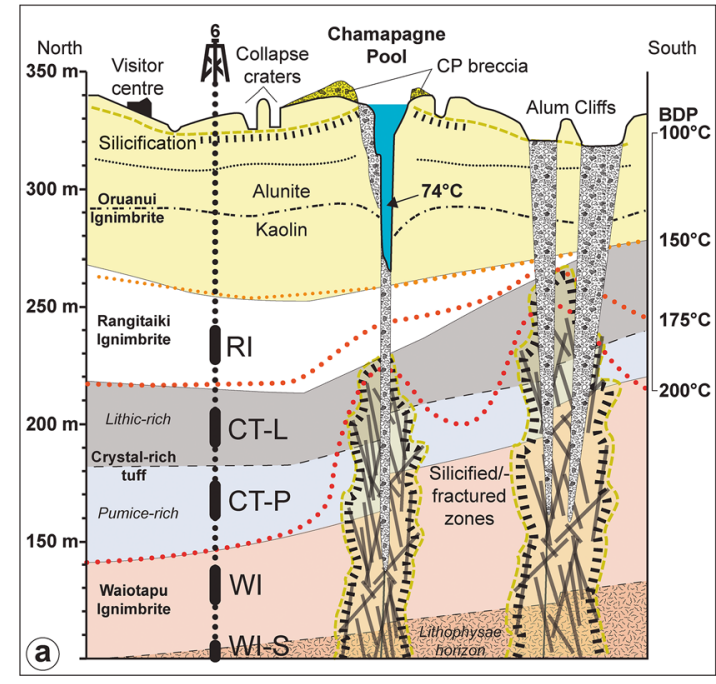

Fig. 2 a Geological section of Champagne Pool (CP) and nearby Alum Cliffs, (see line A-B on Fig. 1), including the main lithological units, alteration/silicification zones, fractures, and surficial features, as well as the projected location of drill hole no. 6 (modified from Hedenquist and

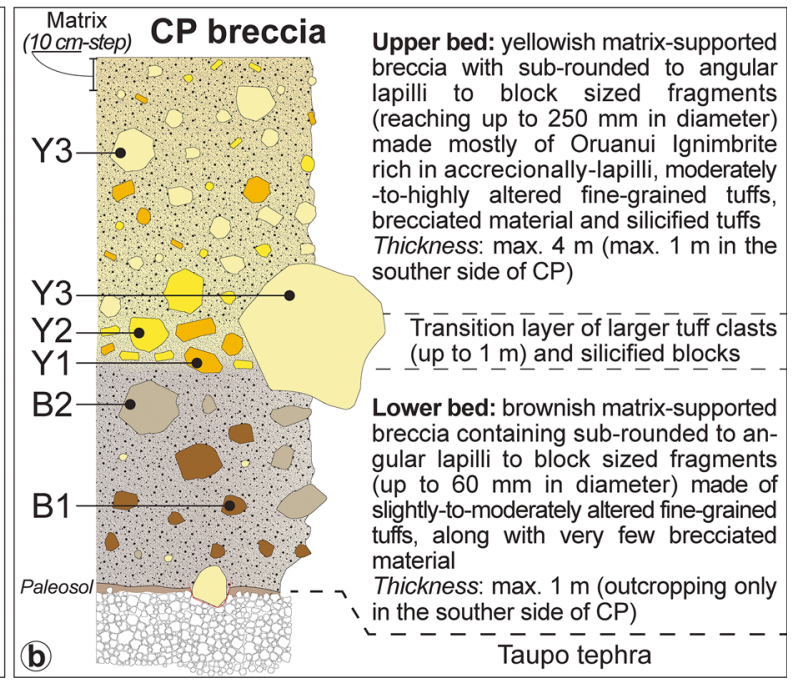

Henley 1985). Approximate depths of sampled units (RI, CT-P and CTL, WI, and WIS) from the 1956-1958 drill core no. 6 are also shown. b Type section (location A in Fig. 1) of CP breccia deposit, showing details of the two main beds, and the position of samples (B1-B2, Y1-Y3) 
hot gases) to "prime" the steam-driven eruptions (Nairn et al. 2005).

The $\sim 60-65-\mathrm{m}$-diameter Champagne Pool crater has an upward-flaring form, with a maximum water depth of $70 \mathrm{~m}$, and an approximate volume of $5 \times 10^{4} \mathrm{~m}^{3}$ (Hedenquist and Henley 1985). The upper 9-m-deep, broad flared part of the pool is entirely within the unconsolidated Oruanui ignimbrite deposits. The pool floor also has an irregular bottom on the northern side, caused by collapsed large blocks from the crater wall (Fig. 2a). The stratigraphy below the present-day Champagne Pool (Fig. 2a), from the deepest to the shallowest units recognised, include:

- The Wai-o-tapu ignimbrite (WI), a moderately to highly welded quartz-poor lenticular ignimbrite with spherulitic zones and lithophysae facies (WIS) at depth $>170 \mathrm{~m}$ (Hedenquist and Henley 1985).

- The "crystal-rich tuff" (CT), a moderately welded coarsegrained quartz and biotite-bearing ignimbrite between 170 and 110-100-m depth (Hedenquist and Henley 1985), comprising a deeper pumice-rich facies (CT-P), and a shallower lithic-rich facies (CT-L).

- The Rangitaiki ignimbrite (RI), a moderately welded quartz-rich fine-grained ignimbrite deposit between 110-100 to $\sim 80-70 \mathrm{~m}$ (Hedenquist and Henley 1985; Hedenquist and Browne 1989), correlated as the Te Whaiti ignimbrite (Leonard et al. 2010).

- The Oruanui ignimbrite (OI), deposited from pyroclastic flows of the $26.5 \mathrm{ka}$ Oruanui eruption, between $\sim 80-70$ and $\sim 1.5-\mathrm{m}$ depth, comprising primarily ash-rich nonwelded rhyolitic deposits with common accretionary lapilli (Van Eaton and Wilson 2013).

- A palaeosol of up to $0.5 \mathrm{~m}$ formed in volcanic ash capped by $<1$-m-thick tephra from the 1.8-ka Taupo eruption (Hedenquist and Henley 1985), in turn capped by recent soil.

\section{Field study}

We documented the breccia deposit along the tourist tracks around Champagne Pool crater (Fig. 1b), to avoid damage to the vegetation within the Wai-o-tapu Thermal Wonderland nature reserve. We sampled the ash- and lapilli-rich breccia matrix, as well as blocks representative of the main lithologies, to be used for component and grain size analyses. Examination of macroscopic alteration features (e.g. colour differences), as well as the occurrence of alteration halos and silicified crusts and veins, indicated the relative degree of alteration within the breccia. We compared breccia-derived material with drill hole samples to infer eruptive source lithologies and excavation depth. Additional information of the field study are reported in the Online Resources.

\section{Drill hole materials}

We collected samples from the seven drill cores collected in 1956-1958 (WT 1-7) and stored within the Geothermal Collection at the University of Auckland. Material was sampled from the drill hole WT-6 located in close proximity to Champagne Pool (Figs. 1 and 2). The cored samples (Figs. 2a and 3a) include densely welded tuff, purple-grey coloured, with lithoidal spherules and lithophysal cavities, derived from the lithophysal zone of the Waiotapu ignimbrite (WIS); densely welded tuff, purple-grey in colour with pumice-rich lenses derived from the Waiotapu ignimbrite (WI); coarse-grained, grey-coloured, pumice-rich tuff (CT-P); moderately dense, grey-coloured, coarse-grained tuff rich in crystals and lithics (CT-L); and fine-grained, dark-grey, crystal-rich tuff of the Rangitaiki ignimbrite (RI).

\section{Breccia stratigraphy}

The breccia erupted from the Champagne Pool has an oval surface distribution with its long axis directly towards the north (Fig. 1b). Immediately south of the crater $(<20 \mathrm{~m})$, the deposit is $1.5 \mathrm{~m}$ thick (Fig. 1b), but it thins to zero, within $100-120 \mathrm{~m}$. By contrast, the breccia is $\sim 4 \mathrm{~m}$ thick at 50 $100 \mathrm{~m}$ north of the crater and is still $\sim 1 \mathrm{~m}$ thick at a $200-\mathrm{m}$ distance northward. The breccia is characterised by two main beds showing distinctive matrix colour and matrix/block componentry.

The $\leq 1$-m-thick lower brown-coloured bed is lenticular in shape and is distributed southward of the crater, although the lack of exposure means that we cannot exclude any deposit to the north. It is dominated by a brownish coarse ash-rich matrix and supports sub-rounded to angular lapilli to blocks up to $60 \mathrm{~mm}$ in diameter. The blocks in the lower bed comprise slightly to moderately altered fine-grained tuff, along with few blocks of silicified and brecciated material (e.g. B1-B2; Figs. 2, 3a, and 4).

The upper yellow-coloured breccia bed is more extensive and encircles Champagne Pool (Figs. 1, 2, and 4). It reaches a maximum thickness of $1 \mathrm{~m}$ south of the crater, and up to $4 \mathrm{~m}$ to the north. It comprises a fine ash-rich matrix, containing sub-rounded to angular lapilli-to-block-sized fragments up to $250 \mathrm{~mm}$ in diameter. The blocks comprise mostly moderately to highly altered fine-grained and accretionary lapilli-rich tuffs, silicified and brecciated clasts, and breccia tuffs (e.g. Y1-Y3 Fig. 2). Rare sintered clasts and tuffs with spherulitic texture occur in the upper half of the bed.

The two beds are separated by an irregular horizon marked by a layer of larger clasts and blocks, up to $1 \mathrm{~m}$ in diameter, forming low- $\left(<50^{\circ}\right)$ to high-angle $\left(>50^{\circ}\right)$ ballistic impact sags into the lower breccia, or impacting within the Taupo tephra (Figs. 2 and $4 \mathrm{a}-\mathrm{f}$ ). These blocks show the greatest 
(a)
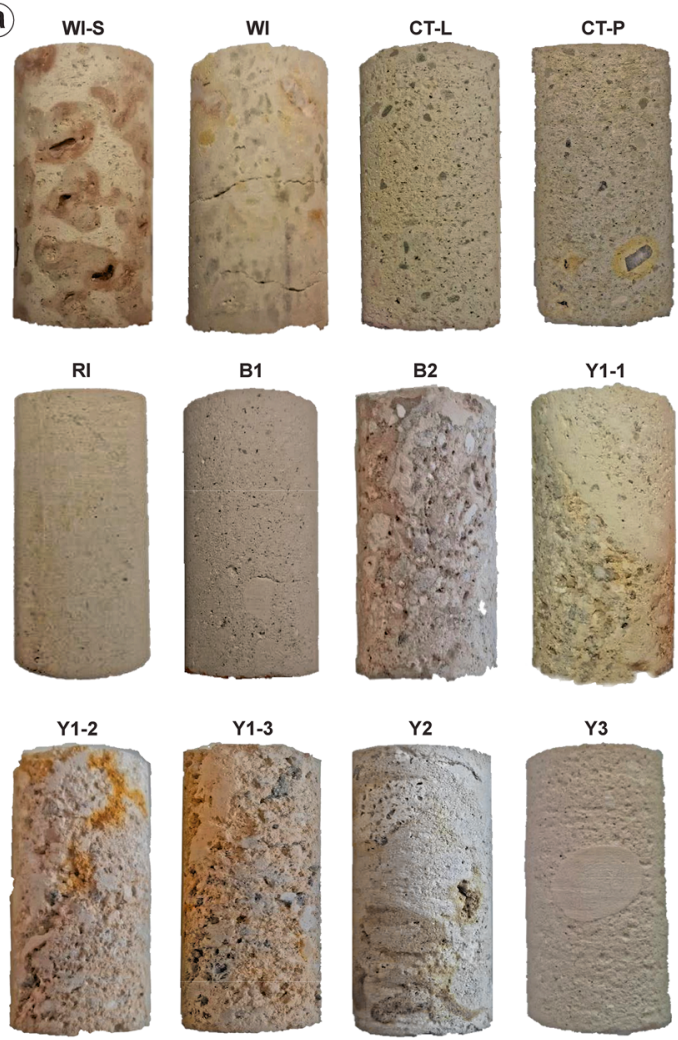

Fig. 3 Cored samples from Wai-o-tapu geothermal drill holes, representative of the main lithologies underlying Champagne Pool (CP) area, and from CP breccia blocks (see also Fig. 2). a Photographs of representative 25-mm-diameter core samples prepared from each of the drill cores (Waiotapu ignimbrite, crystal-rich tuff, and Rangitaiki ignimbrite) and blocks collected from lower and upper bed of $\mathrm{CP}$ breccia. b Bulk density

evidence of alteration, comprising mainly silicified brecciated clasts and breccia tuffs.

\section{Breccia grain size and componentry}

The matrix of the lower bed shows variable grading in particle size while the upper bed shows a general normal grading (Fig. 5a, Figure ESM1 and Table ESM1 in Online Resources). The lower bed shows normal-toreverse grading in the lower $50 \mathrm{~cm}$ (with fine ash, > $3 \phi$ increasing from 0.91 to $1.68 \%$ ), and reverse grading in the upper $50-80-\mathrm{cm}$ interval (returning to $0.53 \%$ fine ash). In the transitional layer between the upper and lower breccia $(80-90 \mathrm{~cm})$, the median diameter (D50) decreases from -2.77 to -2.2 , and fine ash increases from 0.53 to $1.1 \mathrm{wt} . \%$. The upper breccia shows a nor$\mathrm{mal} /$ reverse/normal grading in the matrix from 90 to $140 \mathrm{~cm}$. The content of fine ash reaches its peak of $7.6 \%$ at $90-100 \mathrm{~cm}$, decreases to $0.6 \%$ at 100 $120 \mathrm{~cm}$, and $1.1 \%$ from 120 to $140 \mathrm{~cm}$. Block-sized clasts throughout the upper bed (Fig. 4), do not reflect the matrix grain size variations.

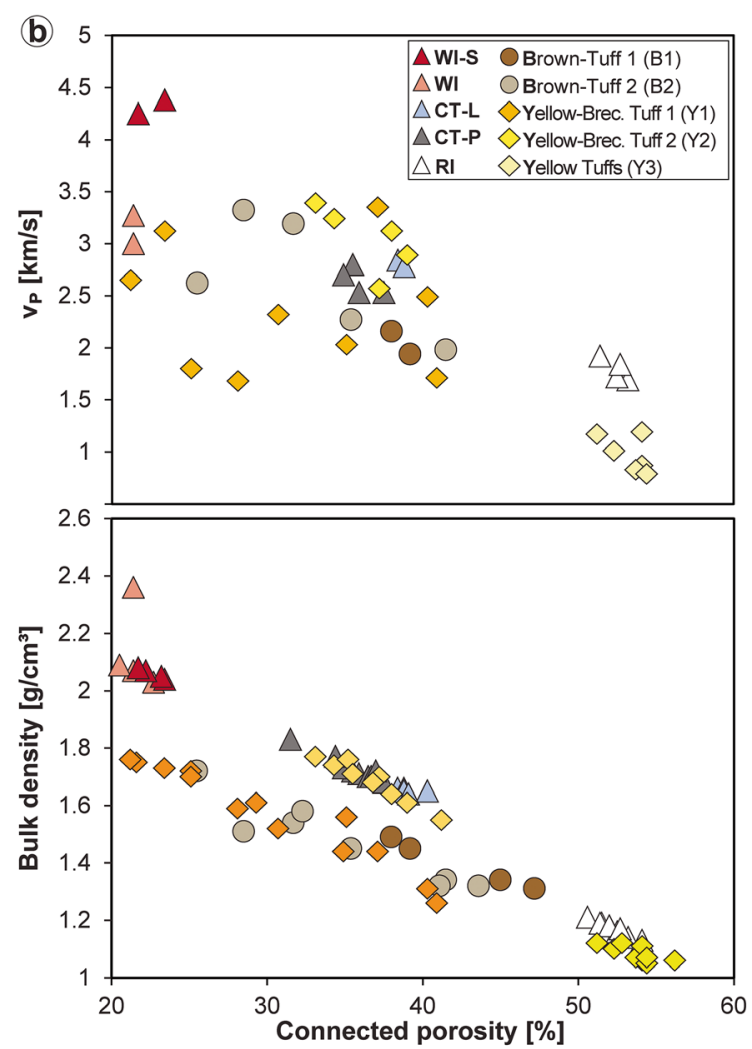

and P-wave velocities $\left(\mathrm{v}_{\mathrm{p}}\right)$ as as a function of connected porosity of representative substrate lithologies involved in the $\mathrm{CP}$ eruption. In the upper graph, only $v_{\mathrm{P}}$ of exploded samples were measured. The experimental error on these measurements is $<1 \%$ and is therefore within the symbol size

Block lithologies vary between beds (Figs. 2b and 3a). The lower bed contains rhyolitic ash-rich tuff, dark-grey coloured, with abundant millimetre-seized pumices and rare accretionary lapilli (e.g. B1) and coarse-grained brecciated tuff, with fine-grained silicified brown ashy matrix containing lithic and pumice clasts (e.g. B2). Upper breccia blocks comprise silicified brecciated clasts and tuff breccia, yellow-coloured, showing a variety of textures including fine-ash tuff with rare fine lapilli (up to $5 \mathrm{~mm}$ ), and coarse lapilli tuffs containing lithics, pumice, and crystals (e.g. Y1-1 to Y1-3 and Y2 Fig. 3a). Some blocks (e.g. Y3) are clearly derived from the OI unit, based on its in situ exposure near Champagne Pool. These consist of friable to weakly consolidated rhyolitic ash-rich tuff with abundant accretionary lapilli. Blocks similar to Y3, but with a siliceous sinter-patina, were common in the block-rich horizon between the lower and upper Champagne Pool breccias, but are rarely found above or below this zone.

The matrix of the two breccia units consists mainly of slightly altered to unaltered fragments of similar tuffs to the blocks, together with pumice, undefined lithics, loose quartz 
Fig. 4 Field appearance of the Champagne Pool breccia (see location in Fig.1). a Type section showing the two main breccia beds, along with the underlying Taupo tephra and Oruanui ignimbrite. b-f Detailed images illustrating several ballistic blocks (varying from silicified, brecciated, and accretionary lapilli-rich blocks) with prominent bomb sags at the contact between the lower and upper breccia bed, and at the contact between the upper bed and the Taupo tephra. $\mathbf{g}$ massive breccia facies of the upper bed rich in large blocks, north of the CP crater. $\mathbf{h}$ Contact between the upper bed deposit and the underlying units, ca. $100 \mathrm{~m}$ south of CP

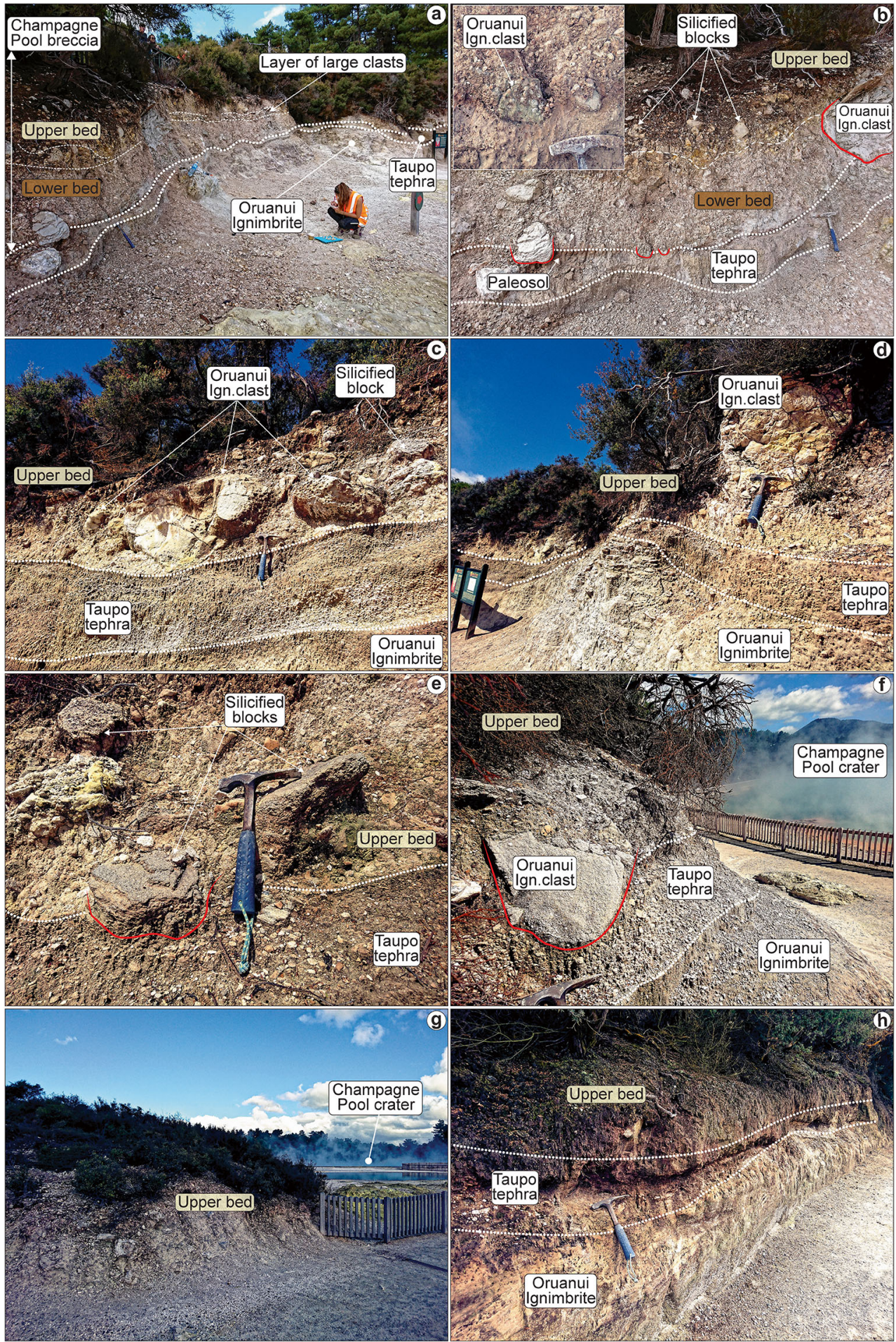

crystals, chlorite, and altered, blue-stained grains (Fig. 5b and Table ESM2 in Online Resources). The lower breccia matrix comprises mainly white tuff clasts $(55-75 \%)$, and quartz crystals $(20-40 \%)$, with $<5 \%$ of the remaining components. From the transitional layer upward, the upper breccia contains common yellow tuff fragments $(>20-70 \%)$, with a secondary abundance of quartz crystals (15-50\%), white tuff (20$30 \%)$, and minor $(<5 \%)$ lithics, pumices, bluish-grey altered clasts, and other crystals. The uppermost part of the upper yellow breccia shows a contrasting zone comprising up to $70 \%$ of dominantly white tuff particles. 

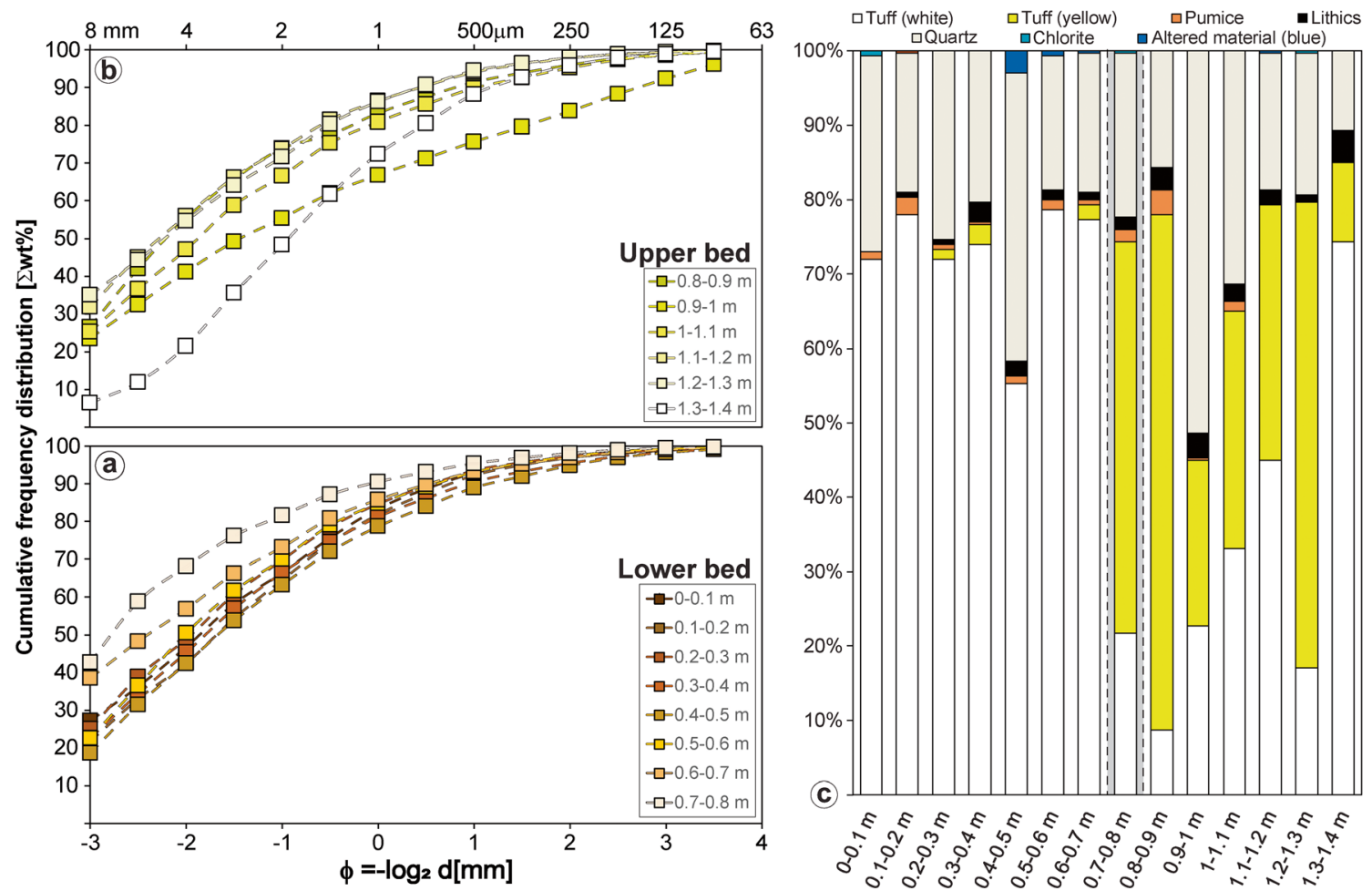

Fig. 5 Grain size distribution (cumulative weight\% passing) of breccia matrix in the a lower and $\mathbf{b}$ upper bed; along with $\mathbf{c}$ componentry of lower and upper bed matrix determined from point counts (300 grains) of $0.5 \mathrm{~mm}$ sieved fraction

\section{Laboratory study}

We measured the bulk/matrix density, (connected) porosity, and P-wave velocities $\left(v_{\mathrm{P}}\right)$ of between four and fifteen cylindrical core samples per lithology type from breccias and drill core samples (Fig. 3) (76 core samples in total). A sub-sample of 33 water-saturated samples were rapidly decompressed in shock-tube steam-flashing experiments (Table 1; Mayer et al. 2015, 2016; Montanaro et al. 2016). Our experiments aimed to mimic the decompression of heated and pressurised fluids at similar conditions as the Wai-o-tapu field, with temperature and pressure conditions described by Hedenquist and Henley (1985) and illustrated in Fig. 2. Our experimental conditions were calibrated using: i) breccia componentry indicating a maximum excavation depth around $170 \mathrm{~m}$ (also noted by Hedenquist and Henley 1985); ii) drill hole pressure data (from WT-6) (Dench 1963); and iii) estimated temperature of equilibration for alteration minerals (Hedenquist and Henley 1985; Hedenquist and Browne 1989). Thus, experimental conditions were between $\sim 210$ and $220^{\circ} \mathrm{C}$, and of 3 to $4 \mathrm{MPa}$ as confining pressures. These conditions, together with the proportion of pore water, were used to estimate the bulk explosive energies fuelling primary fragmentation and clast ejection (Montanaro et al. 2016). We recovered the fragmented and ejected material and analysed grain size distribution and componentry. Finally, we used high-speed footage of the expelled fragments to measure ejection velocities
(Mayer et al. 2015), and pressure sensors above and below the samples to record fragmentation velocities (Scheu et al. 2008).

The main methodological approach for petrophysical property analyses, decompression experiments, and estimation of explosivity of water have already been detailed by us in (Mayer et al. $(2015,2016)$ and Montanaro et al. (2016); we thus do not restate these methodological details here. However, for further detail on the methodological approach applied here, see Online Resources 1, 2, and 3, respectively.

\section{Petrophysical properties and textures}

Samples from drill cores show narrow ranges of porosity which distinguish each lithological unit (Fig. 3b and Table ESM3 in Online Resources). The deeper-derived WI and WIS samples have porosities between 20.5 and 23.4\%; intermediate-depth CT-L and CT-P samples show porosities from 31.5 to $40.3 \%$; whereas the shallow-seated RI samples yield porosities between 50.6 and $54.1 \%$. The measured bulk/ matrix densities profile mirrors the P-wave velocity profile (Fig. $3 \mathrm{~b}$ and Table ESM3 in Online Resources), with the seismic velocities for the more porous RI ( 1.7 to $1.9 \mathrm{~km} / \mathrm{s}$ ) being much lower than those for the less porous and denser CT-P/L and WI/WIS ( 2.5 to $4.4 \mathrm{~km} / \mathrm{s}$ ). In general, these properties strongly correlate to rock textures, with lower porosity/high density and high $v_{\mathrm{P}}$ values associated with densely welded and heterogeneous tuffs, and mid-high porosity/lower density and 
Table 1 Experimental conditions (rock connected porosity, mass of water, pressure, temperature), and estimated/measured parameters including explosive energy $\left(E_{\text {Expl }}\right)$, fragmentation $\left(v_{\text {Frag }}\right)$, and particle ejection $\left(v_{\text {Ejec }}\right)$ velocities, amount of fine $>3 \phi$ and median grain size (D50)

\begin{tabular}{|c|c|c|c|c|c|c|c|c|c|c|c|}
\hline Sample & $\begin{array}{l}\text { Porosity } \\
(\%)\end{array}$ & $\begin{array}{l}\mathrm{H}_{2} \mathrm{O} \\
(\mathrm{g})\end{array}$ & $\begin{array}{l}\mathrm{P} \\
(\mathrm{MPa})\end{array}$ & $\begin{array}{l}\mathrm{T} \\
\left({ }^{\circ} \mathrm{C}\right)\end{array}$ & $\begin{array}{l}E_{\text {Expl }} \\
\left(\mathrm{MJ} / \mathrm{m}^{3}\right)\end{array}$ & $\begin{array}{l}v_{\text {Frag }} \\
(\mathrm{m} / \mathrm{s})\end{array}$ & $\begin{array}{l}v_{\text {Frag SD }} \\
( \pm \mathrm{m} / \mathrm{s})\end{array}$ & $\begin{array}{l}v_{\text {Eject }} \\
(\mathrm{m} / \mathrm{s})\end{array}$ & $\begin{array}{l}v_{\text {Eject SD }} \\
( \pm \mathrm{m} / \mathrm{s})\end{array}$ & $\begin{array}{l}>3 \phi \\
\text { (wt } \%)\end{array}$ & $\begin{array}{l}\text { D50 } \\
(\phi)\end{array}$ \\
\hline $\begin{array}{l}\text { WIS } \\
2.1^{*}\end{array}$ & 23.4 & 4.6 & 3.9 & 220 & 8.4 & I & I & / & I & 1.4 & -3.14 \\
\hline $\begin{array}{l}\text { WIS } \\
2.4^{*}\end{array}$ & 21.7 & 5.2 & 3.98 & 221 & 8.7 & I & / & / & I & 0.2 & -3.2 \\
\hline WI 1.1* & 21.4 & 3.6 & 2.96 & 212 & 8.4 & / & I & / & I & 2.7 & -2.66 \\
\hline WI $1.2 *$ & 21.4 & 3.9 & 4 & 220 & 8.9 & I & / & / & / & 4 & -1.76 \\
\hline CT-P 1.2 & 33.5 & 9.8 & 4 & 228 & 15.7 & 226 & 4 & 200 & 25 & 8.1 & 0.75 \\
\hline СТ-P 1.3 & 34.9 & 9.4 & 3.9 & 224 & 14.8 & 253 & 13 & 212 & 23 & 9 & 0.75 \\
\hline СТ-P 1.4 & 35.9 & 12 & 3 & 210 & 13.4 & 219 & 3 & 181 & 18 & 7.3 & 0.76 \\
\hline CT-P 1.8 & 37.5 & 8 & 3 & 210 & 13.7 & 157 & 8 & 190 & 9 & 5.5 & 0.88 \\
\hline CT-L 1.2 & 38.4 & 8 & 3 & 210 & 13.8 & 135 & 2 & 231 & 17 & 7.3 & 0.33 \\
\hline CT-L 1.4 & 38.8 & 10.2 & 4 & 220 & 16.4 & 188 & 6 & 235 & 13 & 5.4 & 0.42 \\
\hline RI1.1 & 53.2 & 13.2 & 3 & 210 & 19.8 & 37 & 1 & 211 & 14 & 14.3 & 1.97 \\
\hline $\mathrm{RI} 1.2^{\#}$ & 52.5 & 13.7 & 4 & 220 & 21.2 & 103 & 1 & 1 & I & 11.6 & 2 \\
\hline RI2.1 & 51.4 & 7.9 & 4 & 220 & 20.4 & 209 & 20 & 247 & 11 & 20.6 & 1.75 \\
\hline RI2.3 & 52.7 & 7.5 & 3 & 210 & 19 & 176 & 8 & 187 & 16 & 19.8 & 1.78 \\
\hline B1.1 & 39.2 & 7.7 & 4 & 216 & 15.5 & 133 & 2 & 181 & 3 & 18.4 & 1.45 \\
\hline B1.2 & 38 & 7.6 & 3.1 & 211 & 13.7 & 189 & 5 & 177 & 20 & 9.2 & 1.63 \\
\hline B2.3* & 25.5 & 4.8 & 5 & 230 & 11.1 & I & I & / & I & 1.7 & -1.25 \\
\hline B2.4* & 28.5 & 6.3 & 4 & 220 & 11.4 & I & I & / & I & 5.1 & -1.21 \\
\hline B2.7* & 32.3 & 4.7 & 4.1 & 220 & 12.5 & I & I & I & I & 4.7 & -1.1 \\
\hline Y1.3 & 35.1 & 7.7 & 3 & 210 & 12.8 & 58 & 2 & 169 & 7 & 3.5 & -0.67 \\
\hline Y $1.8^{*}$ & 28.1 & 8.2 & 4.15 & 221 & 11.4 & 1 & I & 1 & I & 2.4 & -0.71 \\
\hline Y1.10 & 40.9 & 7.9 & 3.9 & 220 & 18.1 & 121 & 30 & 229 & 28 & 3.5 & -0.29 \\
\hline $\mathrm{Y} 1.12$ & 31 & 7 & 4 & 220 & 12.6 & 10 & & 194 & 10 & 2 & -1.13 \\
\hline $\mathrm{Y} 1.14 \mathrm{~A}^{*}$ & 23.4 & 5.5 & 3 & 210 & 9 & I & I & / & 1 & 2 & -1.11 \\
\hline Y1.15B* & 25.1 & 5.5 & 3 & 214 & 9.5 & I & I & I & / & 3.9 & -1.55 \\
\hline Y2.1 & 34.3 & 9.8 & 3 & 210 & 12.3 & I & I & 163 & 12 & 11.3 & 0.33 \\
\hline Y2.7 & 37.2 & 7.4 & 3 & 209 & 13.7 & 142 & 4 & 150 & 18 & 18.1 & 0.7 \\
\hline Y 2.10 & 33.1 & 5.9 & 4 & 220 & 13.3 & 208 & 4 & 234 & 18 & 13.6 & -0.49 \\
\hline $\mathrm{Y} 2.12^{\#}$ & 39 & 10.6 & 4 & 220 & 15.9 & 178 & 3 & 1 & 1 & 14.1 & 0.45 \\
\hline Y $3.1^{\#}$ & 51.2 & 11.1 & 4 & 220 & 18.9 & 162 & 13 & I & I & 32.1 & 2.23 \\
\hline Y $3.2^{\#}$ & 52.3 & 11 & 3.6 & 210 & 17 & 277 & 24 & I & 1 & 31.2 & 2.33 \\
\hline Y3.5 & 53.7 & 10.8 & 3 & 210 & 17.4 & 217 & 5 & 197 & 15 & 33 & 2.4 \\
\hline Y3.8 & 54.4 & 8.7 & 4 & 220 & 20.2 & 149 & 3 & 239 & 6 & 33.9 & 2.4 \\
\hline
\end{tabular}

*Partially fragmented samples; ${ }^{*}$ fragmentation/ejection velocities not measurable

low $v_{\mathrm{P}}$ values typical of pumice/lithic- and ash-rich mildly to weakly compacted tuffs.

Breccia block samples show variable ranges of porosity depending on their stratigraphic position, lithology, and texture (Fig. $3 \mathrm{~b}$ and Table ESM3 in Online Resources). From the lower bed, homogeneous B1 samples have porosities ranging between 38 and $45 \%$, while the brecciated and texturally diverse B2 samples show a broader range (25.5 to $43.6 \%$ ). Cores from the highly variegated $\mathrm{Y} 1$ show the widest porosity range (21.2 to $40.9 \%$ ), while Y2 porosities vary between 33.1 and $41.2 \%$. Y3 samples show the highest porosity measured (51.2 to $56.2 \%$ ). A wider range of bulk/matrix densities and Pwave velocities were measured for the breccia blocks (Fig. 3b and Table ESM3 in Online Resources); the most porous Y3 show the lowest seismic velocities $(0.8$ to $1.2 \mathrm{~km} / \mathrm{s})$, while the brecciated clasts and tuff breccia (B2, Y1, Y2) show a wide and scattered range of values (1.7 to $3.4 \mathrm{~km} / \mathrm{s}$ ), and B1 exhibit intermediate values $(1.9$ to $2.2 \mathrm{~km} / \mathrm{s})$. 


\section{Explosive energy derived from experimental conditions}

Bulk explosive energies are estimated assuming an irreversible (isenthalpic) flashing of pore waters (Thiéry and Mercury 2009; Montanaro et al. 2016) from initial experimental conditions $\left(\sim 210-220{ }^{\circ} \mathrm{C}\right.$ and $\left.3-4 \mathrm{MPa}\right)$. These values average between 8.4 and $21.2 \mathrm{MJ} / \mathrm{m}^{3}$ for a porosity range between 21.4 to $54.4 \%$ (Table 1$)$. Low-porosity samples $(\sim 20-30 \%)$, including drill core samples WI, WIS, and brecciated blocks B2, Y1, reached between 85 and $100 \%$ of water saturation, leading to an energy release of between 8.4 and $12.5 \mathrm{MJ} / \mathrm{m}^{3}$. Mid-porosity samples ( $\sim 30$ to $\sim 41 \%$ ), including CT-P/L and B1, Y1, Y2 reached pore saturation between 92 and $100 \%$ equating an energy release of 12.6 to $18.1 \mathrm{MJ} / \mathrm{m}^{3}$. Highly porous RI and Y3 (51.2-54.4) only saturated between 84 and $96 \%$ accounting for energy release between 17 and $21.2 \mathrm{MJ} / \mathrm{m}^{3}$.

Decompression experiment results show how the explosive energy is coupled with porosity, scattering due to the initial pressure/temperature experimental conditions, and natural variability/degree of saturation of the core samples (Fig. 6a). All samples with $<30 \%$ porosity did not fragment completely. Only $30-60 \%$ of each of these samples fragmented, independent of the initial pressure/temperature conditions.

\section{Grain size distributions of experimentally fragmented samples}

The median grain size and the amount of fine ash generated by experiments (Table 1) show higher proportions of fines for conditions with higher fragmentation energy (Fig. 6b, c). Grain size distributions from fragmented drill core samples are finer (Fig. 7a) as a function of increasing sample porosity. WI and WIS generally produced the coarsest grain size distributions (WIS1: D50 from -1.76 to $-2.66 \phi$; WIS2: D50 from -3.14 to $-3.20 \phi)$ with little fine ash $(<4 \mathrm{wt} \%)$. We note that these samples did not completely fragment $(<1 / 3$ of the whole sample). Experiments on CT-P and CT-L show very similar trends, with the pumice-rich CT-P producing a slightly lower median grain size than CT-L (0.75-0.88 $\phi$ vs. $0.33-0.42 \phi$ respectively). Both CT-P and CT-L produced similar amounts of fine ash (5.5-9 vs. 5.4-7.3 wt\%). The RI sample series produced the finest median grain size (from 1.75 and $2 \phi$ ) and the highest amount of fine ash (11.6 and $20.6 \mathrm{wt} \%)$.

Grain size distributions from breccia block samples span from very coarse to very fine (Fig. 7b-d), in a similar pattern to the drill core samples. The fine-grained B1 samples, are very similar to RI, and produced median grain sizes of 1.45$1.63 \phi$, and a large proportion of fine ash $(9.2-18.4 \mathrm{wt} \%)$. Brecciated B2 samples only partially fragmented $(<2 / 3$ or $<$ $1 / 3$ of the whole sample), and produced a coarse grain size distribution with median grain sizes from -1.08 to $-1.25 \phi$,
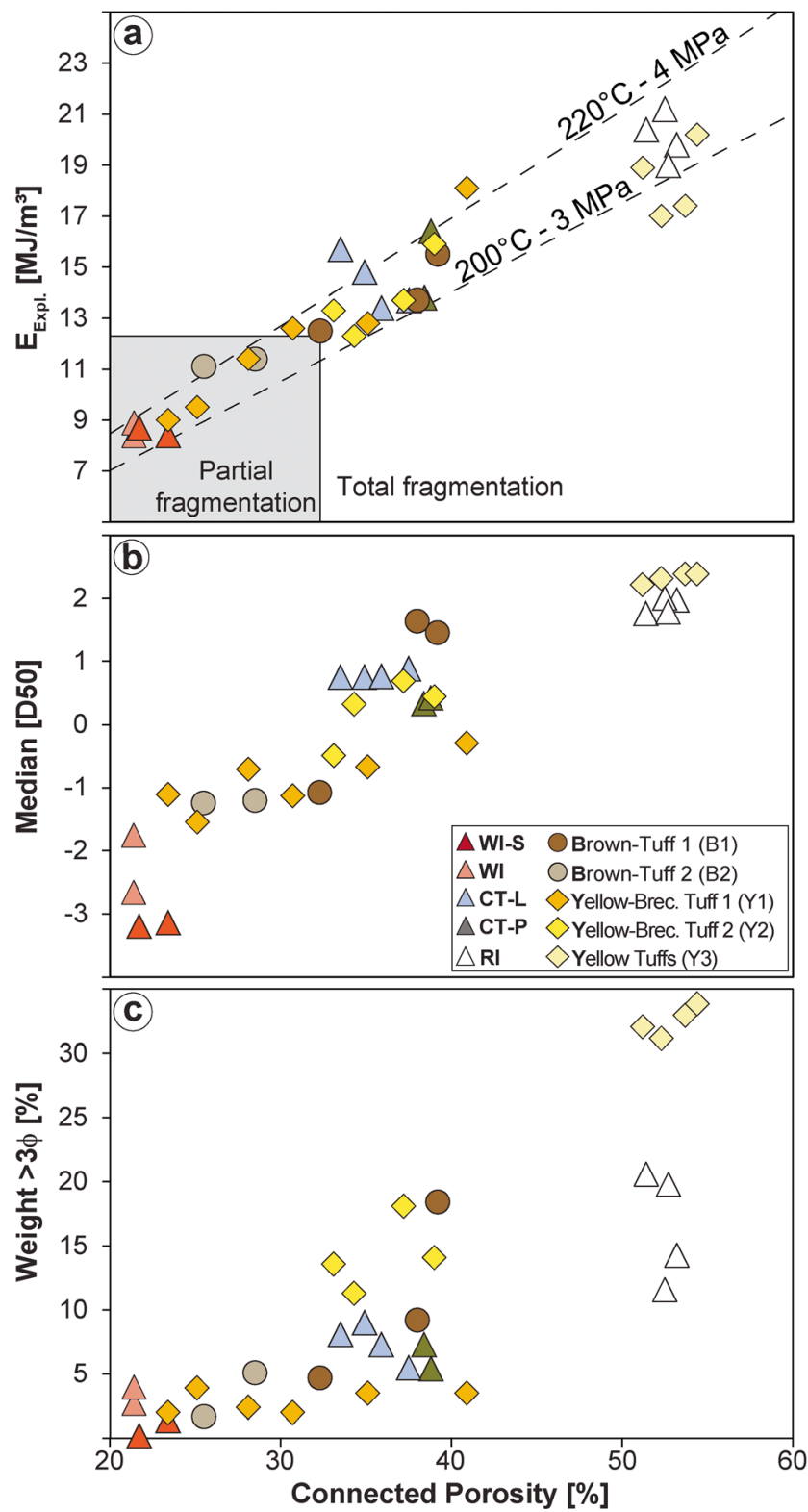

Fig. 6 Explosive energies ( $\left.E_{\text {Expl }}\right)(a)$, median grain size (b), and weight $\%$ of fine ash $(3 \phi)$ (c) of experimentally produced fragments as a function of samples porosities (in a iso-energetics are calculated based on the experimental conditions). Cases with porosity $<32 \%$ do not have sufficient energy to completely fragment the samples and produce few coarse clasts with a small quantity of fine ash. In cases with porosity $>32 \%$, for all initial pressure-temperature conditions tested, the entire sample is fragmented and these experiments produce finer grain sizes and larger amount of fine ash. The scattering in the explosive energy reflects the natural variability in sample textures

and low amounts of fine ash (1.7-5.1 wt\%); the latter depending on the initial proportion of fine-grained matrix in the cored sample. For Y1 samples, the low-porosity samples $(\sim 23-$ $28 \%$ ) only partially fragmented $(<2 / 3$ of the whole sample), resulting in coarse grain size distributions with a median between -1.55 and $-0.7 \phi$. Mid-porosity Y1 samples $(\sim 31-$ $41 \%$ ), completely fragmented, generating fine median sizes 

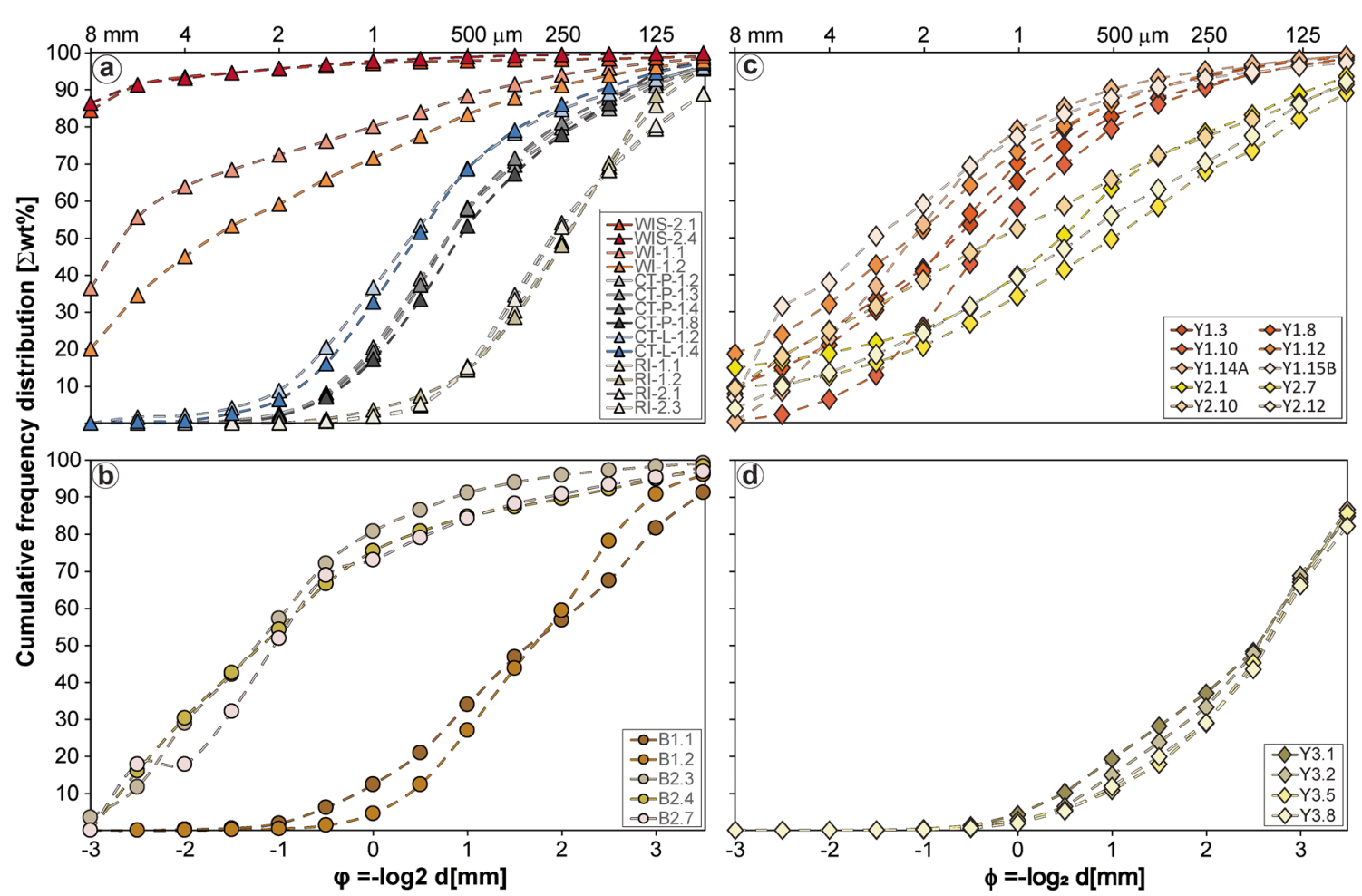

Fig. 7 Grain size distribution (cumulative weight percent passing) of experimentally produced fragments from samples from drill cores (a), and CP breccia blocks from the lower (b) and upper bed $(\mathbf{c}, \mathbf{d})$

from -1.1 to $-0.29 \phi$. Both sample suites produced small amounts of fine ash (2-3.9 wt\%). Tuff breccia Y2 samples produced grain size distributions intermediate between CT-P/ $\mathrm{L}$ and RI, with a coarse median diameter $(-0.49$ to $0.7 \phi)$, and moderate amounts of fine ash (11.3 to $18.1 \mathrm{wt} \%)$. Y3 samples produced finer median grain sizes $(2.23-2.40 \phi)$ than B1 or RI and a significant proportion of fine ash (31.2-33.9 wt\%).

\section{Grain componentry of experimentally produced grains}

The experimentally produced fragments from drill core and breccia block samples have similar componentry to the Champagne Pool breccia matrix (Fig. 5), but also include additional grey tuff, silicified material, and crystals of calcite and mica (Fig. 8, Figures ESM3, 4 and Table ESM4, 5 in Online Resources). The samples that only partially fragmented show similar components in similar proportions to the fully fragmented samples.

In the fragmented drill core samples (Fig. 8a), the white tuff represents the dominant component, especially for the WI, WIS, and RI samples, with amounts varying from 60 to $>90 \%$. The second most common components are loose quartz crystals, varying between rock types: WI (4-6.7\%), WIS $(\sim 10 \%)$, CT-P $(33-49 \%)$, and CT-L $(38-47 \%)$, while being absent in the RI. Calcite crystals, only found in WI, WIS, and CT-L, vary in quantity between 6 and $8 \%$. WI and
WIS are the only drill core samples containing K-feldspar crystals $(2-15 \%)$ and silicified material (10\%). The CT-P fragments mostly consist of white tuff (35-40\%) and quartz (46-49\%), with one sample rich in yellow tuff $(42 \%)$, and containing common pumices (9-10\%). The CT-L fragments are richer in chlorite $(15-18 \%)$. The RI is mostly made of white (85-93\%) and grey tuff (4 to 15\%). Lithics fragments vary between 0.3 to $12.7 \%$, while rare mica $(<2 \%)$ is only found in the CT-P.

Within the fragmented material of brecciated clasts and tuff breccia (Fig. 8b), especially in fine-grained samples of $\mathrm{B} 1, \mathrm{Y} 2$, and $\mathrm{Y} 3$, white tuff is the dominant component ( $\sim 30$ to $76 \%$ ), quartz crystals make up 16 to $49 \%$. Most of the brecciated samples from B2 and Y1 are instead dominated by silicified material ( $\sim 40$ to $70 \%)$, with minor white tuff (10-36\%) and quartz (5-22\%). Only one finegrained sample of Y1 contained white tuff fragments $(79 \%)$ and minor silicified clasts $(10 \%)$. Yellow tuff is found in small amounts $(\sim 1-7 \%)$ by $\mathrm{B} 2, \mathrm{Y} 1$, and $\mathrm{Y} 2$ samples, besides one Y2 sample showing $\sim 21.7 \%$. Pumice fragments are found in all exploded samples, especially from Y2, with quantities varying between 1 and $14 \%$. Lithics fragments were generated from all samples and make up between $<1$ to $10 \%$ of the particles. Chlorite is only found as a minor component $(<2 \%)$ within fragmented Y1 and Y2 samples. 


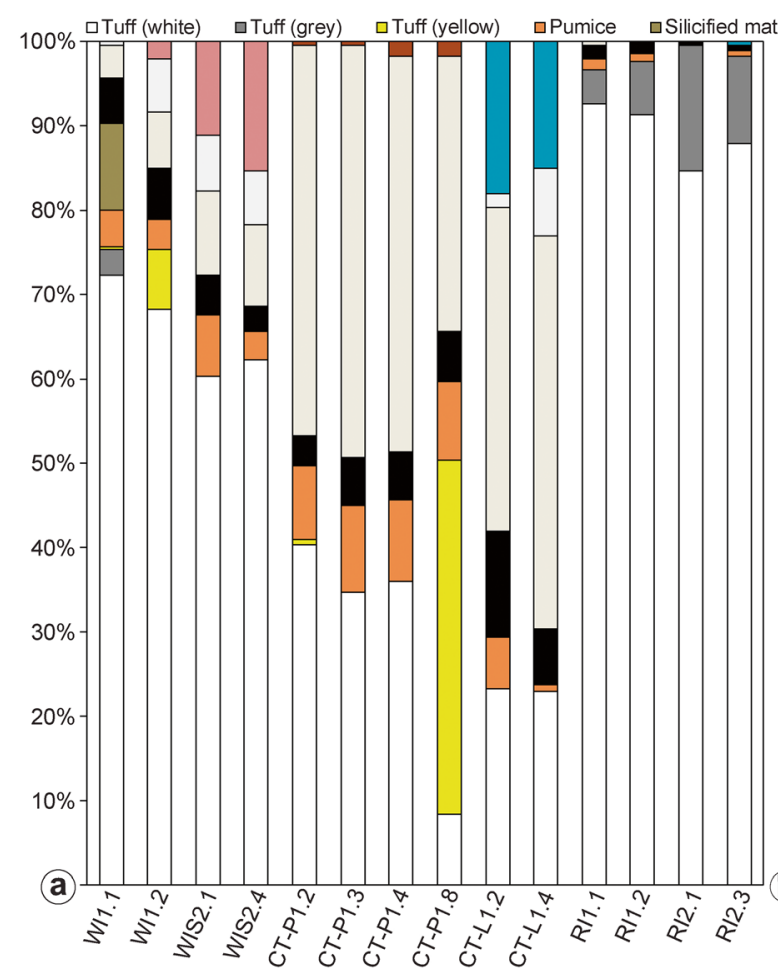

Fig. 8 Componentry of experimentally produced fragments from decompression experiments with drill core samples determined from point counts (300 grains) of $0.5-\mathrm{mm}$ sieved fraction. a Detailed componentry in vol.\% for Waiotapu ignimbrite (typical: WI; lithophysae: WIS), Crystal-rich tuffs (pumice-rich: CT-P; lithic-rich:

The proportions of the main components are similar between the experimentally produced fragments of drill cores and breccia blocks. The only exception is the almost total absence of silicified material in the produced fragments from drill core samples (Table 2, Fig. 8).

\section{Ejection velocities}

Ejection velocities ( $v_{\text {Eject }}$ in Table 1$)$ are computed from the displacements of individual particles tracked across five successive frames of high-speed footage. For a few experiments, the initial part of the plume was obscured by large vapour clouds so that only minimum velocities could be estimated. In general, the ejection velocities weakly correlate with explosive energy (Fig. 9a), with data scatter due to initial pressure/ temperature conditions and natural variability in sample strength (cf., Montanaro et al. 2016).

For the drill core sample series, the CT-P fragments show the lowest velocities $(196 \pm 19 \mathrm{~m} / \mathrm{s})$, with the highest velocities in CT-L $(233 \pm 15 \mathrm{~m} / \mathrm{s})$ and RI $(215 \pm 14 \mathrm{~m} / \mathrm{s})$ samples. Among the breccia block series, B1 samples eject the slowest fragments $(179 \pm 12 \mathrm{~m} / \mathrm{s})$, while higher velocities are reached by particles from Y1 $(197 \pm 15 \mathrm{~m} / \mathrm{s}), \mathrm{Y} 2(182 \pm 16 \mathrm{~m} / \mathrm{s})$, and Y3 $(218 \pm 11 \mathrm{~m} / \mathrm{s})$.

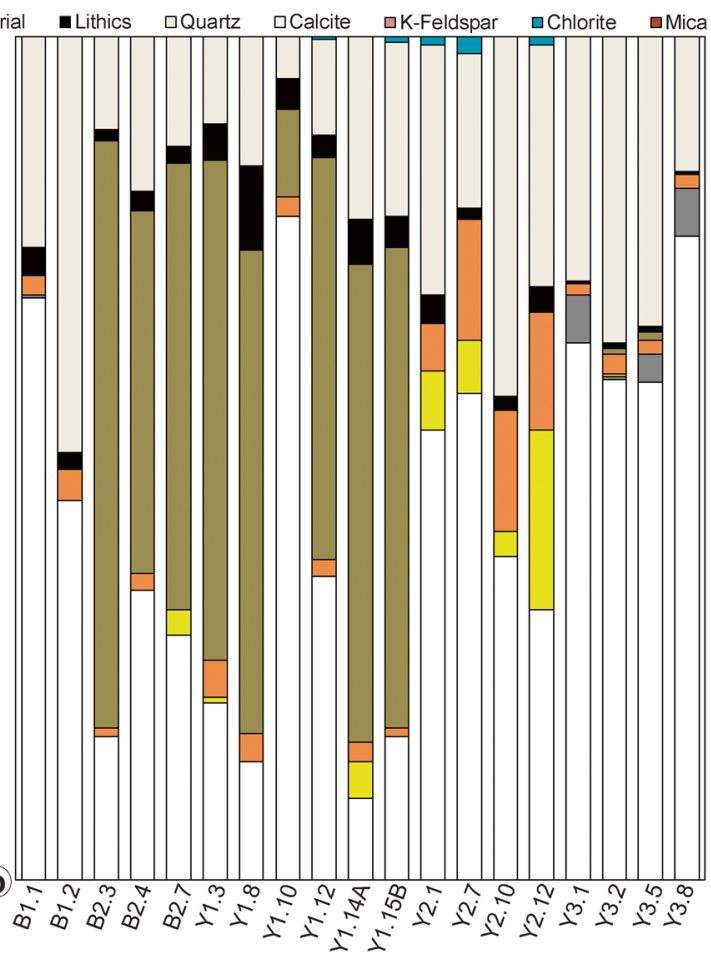

CT-L) and Rangitaiki ignimbrite (RI). b Detailed componentry shown in percentage for brown tuffs (B1) and brecciated clasts (B2) of the lower bed, and for yellow brecciated material (Y1, Y2) and yellow tuffs (Y3) from the upper bed

\section{Fragmentation velocities}

Fragmentation velocities ( $v_{\text {Frag }}$ in Table 1$)$ were measured for all samples that completely fragmented. Fragmentation velocities are generally scattered, with no clear correlation with explosive energy (Fig. 9b). For the drill core series, the CT$P$ samples show higher fragmentation velocities $(214 \pm 7 \mathrm{~m} / \mathrm{s})$ than CT-L $(162 \pm 4 \mathrm{~m} / \mathrm{s})$ and RI $(131 \pm 8 \mathrm{~m} / \mathrm{s})$. Breccia blocks samples show similar ranges, with $\mathrm{Y} 3$ having higher velocities $(201 \pm 11 \mathrm{~m} / \mathrm{s})$ than $\mathrm{Y} 2(176 \pm 4 \mathrm{~m} / \mathrm{s}), \mathrm{B} 1(161 \pm 3 \mathrm{~m} / \mathrm{s})$, and Y1 $(63 \pm 16 \mathrm{~m} / \mathrm{s})$.

\section{Discussion}

\section{Source lithologies of champagne Pool eruption}

Drill core data from the nearby WT-6 core (Dench 1963; Hedenquist and Henley 1985) provide stratigraphic and lithologic control, and insight into local hydrothermal alteration. Noteworthy, among the drill core samples, the only lithology showing silicified material is the deeply seated Waiotapu ignimbrite (Fig. 8). This suggests that in the WT-6 area, fluids circulated and partially altered rocks only within deeper fractures. By contrast, upwelling of silicifying fluids that occurred 
to shallower levels must have occurred via a pre-existing permeable pathway (fracture zone) beneath the present Champagne Pool (Fig. 2). Despite the differences in silicification, there are similarities in componentry (e.g. the abundance of tuff types and minerals) between the experimental results from drill core and breccia clast samples (Fig. 8, Table 2). Considering this, experimentally fragmented material remains a robust proxy to correlate the inherited characteristics of components with the original pre-eruptive lithologies (Geshi et al. 2011). These are used alongside petrophysical properties to fingerprint the host rock involved at different stages of the eruption (cf., Heap et al. 2019).

In the lapilli-to-block-sized fraction, the lower bed of the Champagne Pool breccia is rich in altered fine-grained ashrich tuffs (B1), and silicified brecciated clasts (B2), containing lithics and pumices (Fig. 3a). Their appearance, textures, petrophysical properties, and componentry (Fig. 3, Table 2) suggest that these lithologies originate from fragmented deepseated CT-P/L or RI units. The nature of the breccia block B2 also indicates that a fractured and silicified portion of these units was involved in the eruption. Experimentally produced fragments from B1 show finer grain sizes, but similar componentry to CT-P (Figs. 7 and 8), while partially fragmented B2 samples show coarser sizes and a componentry dominated by silicified material, which are absent in drill core samples.

The lapilli-to-block-sized fraction of the upper Champagne Pool breccia bed is dominated by weakly consolidated ashrich and accretionary lapilli-rich tuffs (Y3), and secondary silicified brecciated clasts (Y1) and tuff breccia (Y2) with variable textures, and containing lithics, pumices, and abundant crystals (Fig. 3, Table 2). The Y3 samples are derived from Oruanui ignimbrite. The fragmentation of such porous, low-density and accretionary lapilli-rich tuffs, results in fine grain sizes generation (Fig.7) and high fragmentation velocity (Fig. 9). Petrophysical properties of mid-porosity brecciated $\mathrm{Y} 1$ cores are similar to CT-P/L, while the low-porosity samples show similar features to WI (Fig. 3). In the experiments the first type of $\mathrm{Y} 1$ cores fragmented completely, generating grain sizes very similar to $\mathrm{B} 2$ and $\mathrm{CT}-\mathrm{P} / \mathrm{L}$, while the second type fragmented only partially, producing size distributions similar to WI (Fig. 7). The componentry of fragmented particles from all Y1 cores are dominated by silicified clasts (Fig. 8 ) with minor white/yellow tuff and lithics. This is very similar to particles produced by fragmentation of silicified CT-P/ $\mathrm{L}$ and WI units. Breccia tuff Y2 samples have petrophysical properties that almost completely overlap those of CT-P/L (Fig. 3b). The experimentally produced fragment size distributions (Fig. 7) and componentry of Y2 include chlorite (Fig. 8 ) and are very similar to those produced by CT-P/L.

The matrix of the lower Champagne Pool breccia bed is dominated by white tuff and quartz, with minor pumice and lithics. Overall, this resembles a mixed componentry derived from CT-P and RI lithologies. The transition layer between the two breccia beds shows an increasing content of yellow tuff, which becomes dominant in the upper bed, together with white tuff and minor quartz, lithics, and pumice. The abundance of yellow tuff in the transition layer could originate from an input of deeper units, or more likely, a greater involvement of the argillic-altered portions of the Oruanui Ignimbrite, where kaolinite and alunite zones produce yellow-coloured alteration products (Fig. 2a; Hedenquist and Henley 1985; Hedenquist and Browne 1989). Caution is needed in comparing these components due to (i) subsurface mixing and sorting occurring during the debris jet emplacement (Graettinger et al. 2015) and (ii) the efficiency of steamflashing in fragmenting the host rock into ash-fine lapilli sizes (Montanaro et al. 2016). For instance, the matrix of both lower and upper bed breccia lacks silicified material, although this is abundant in the coarse lapilli and blocks. This might indicate that fragmentation processes were not efficient for the silicified lithologies (cf., Kueppers et al. 2006).

Decompression experiments showed that low porosity lithologies only partially fragment under the investigated conditions. This is consistent with the absence, or rarity, of WI/ WIS clasts and their components (e.g. the characteristic kfeldspar; Fig. 8), within the breccia blocks and matrix.

\section{Eruption trigger and mechanism}

The lower bed of the breccia includes deep-seated local lithologies such as CT-P and RI, as well as shallow OI clasts at the base of the unit (Fig. 3). The CT-P clasts indicate that the initial explosion began at least at a depth of $\sim 110-100 \mathrm{~m}$ (Fig. 2). In addition, some of the CT-P clasts were brecciated and silicified (Figs. 3 and 10). Similar brecciated and recemented clasts are found in other hydrothermal breccia deposits (e.g. Nairn and Wiradiradja 1980; Hedenquist and Henley 1985; Kennedy et al. 2020; Montanaro et al. 2020) and drill cores from geothermal fields (White et al. 1975; Krupp and Seward 1987; Dobson et al. 2003). Their textures were attributed to hydraulic fracturing (Phillips 1979; Bromley and Mongillo 1994), produced by over-pressurised fluids along fault/fractures that break rocks and precipitate silica along fractures. Such mechanisms generally predate and sometimes trigger explosive events (Nairn and Wiradiradja 1980). Silicification of fractures and pores of surrounding rocks can reduce matrix permeability of hydrothermal reservoir rocks of orders of magnitude, and enhance fracture formation (Heap et al. 2020). Yet, at the same time, silicification may form an effective aquitard or aquiclude horizon (Lowell et al. 1993; Dempsey et al. 2012). Any excess $\mathrm{CO}_{2}$ or other magmatic gas rising from a basaltic dyke (> $1000 \mathrm{t} /$ day; Nairn et al. 2005), would be channelled within fractures within silicified portions of the deeper units (Uysal et al. 2009; Rowland and Simmons 2012), but ultimately trapped by a 


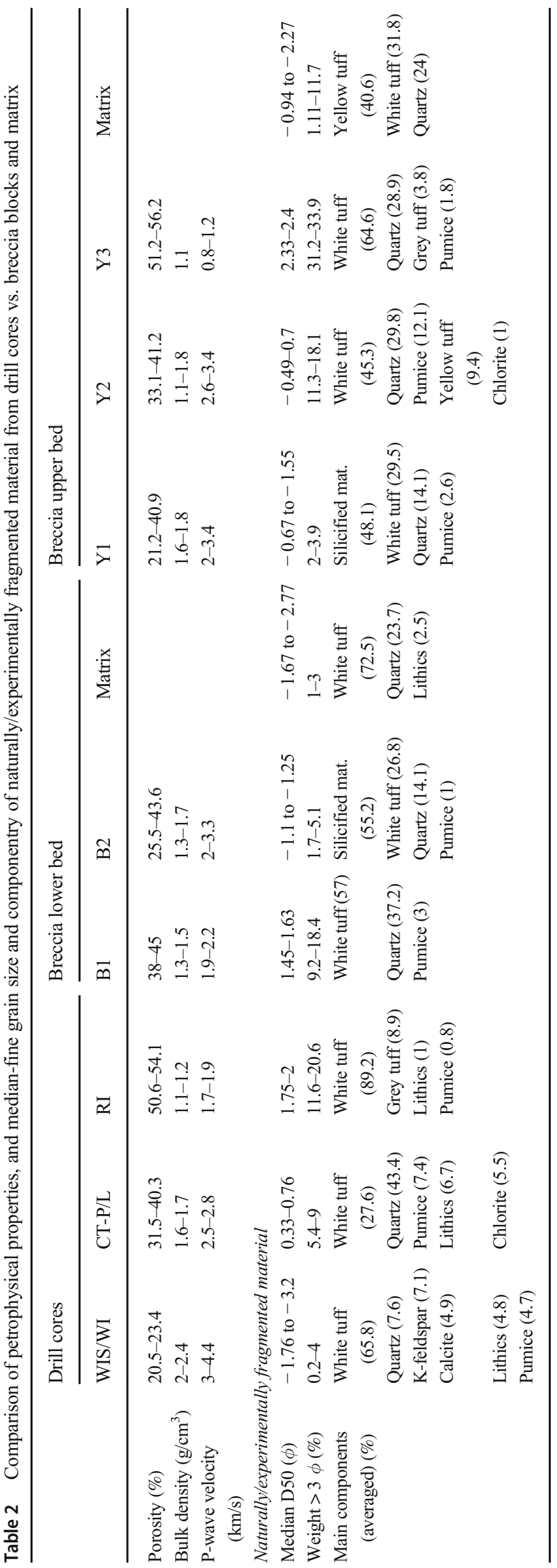

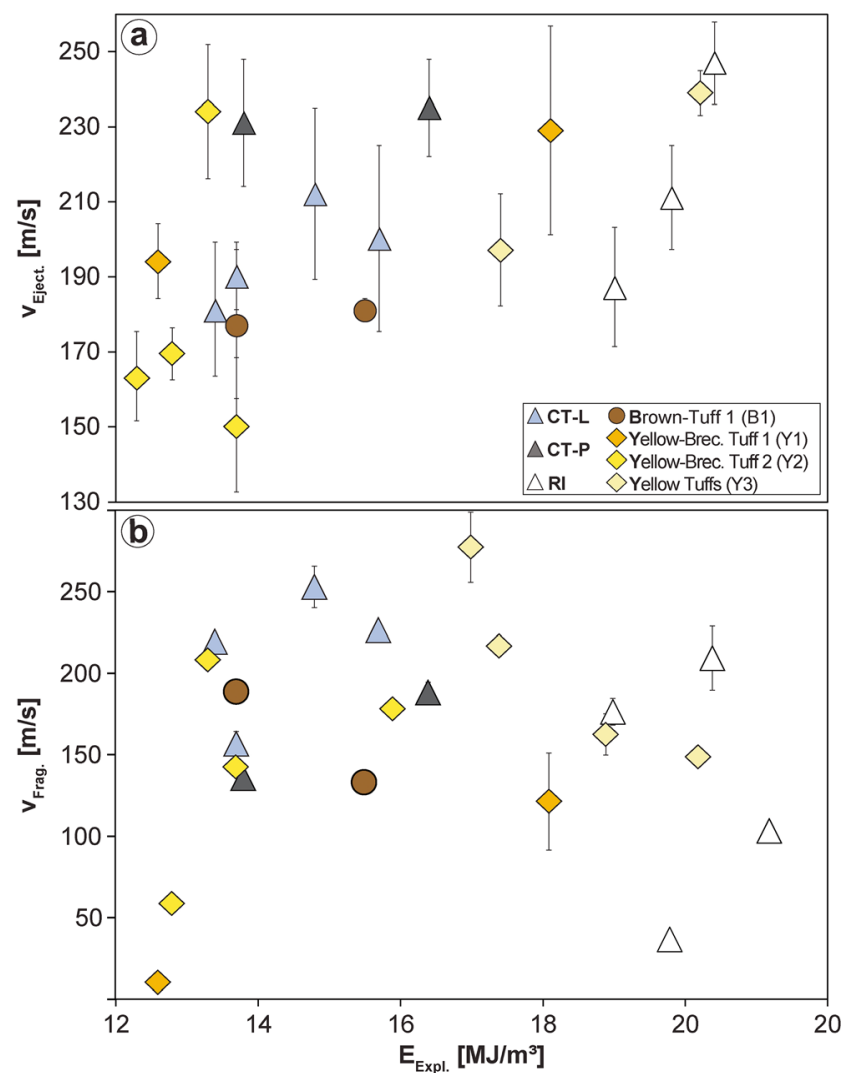

Fig. 9 Experimental results of ejection velocities (a) and fragmentation velocities (b) plotted as a function of bulk explosive energies $\left(E_{\text {Expl }}\right)$

cap rock (e.g. silicified and/or argillic-altered levels). Overpressurization thus leads to hydraulic fracturing and explosive failure (Browne and Lawless 2001; Morgan et al. 2009; Christenson et al. 2010; Rosi et al. 2018; Stix and Moor 2018; Heap et al. 2019). A pressurised aquifer likely breaches near a horizontal discontinuity, such as a textural break, or cap/seal layer (Stearns and McDonald 1949; Browne and Lawless 2001). This leads to a top-down rarefaction wave, in concert with a returning pressure wave that fragments and ejects clasts (Germanovich and Lowell 1995; Montanaro et al. 2020). This mechanism explains the opening stage of the Champagne Pool eruption, recorded by emplacement of the lower breccia bed (Fig. 10).

The limited distribution of the lower bed and the high-angle ballistic impact sags (Fig. 4a, b), suggest that the initial crater was located close to the current pool with deep-seated explosions forming a narrow, diatreme-like crater (Maeno et al. 2013; Taddeucci et al. 2013). Variation in the upper breccia bed componentry and its broader irregular distribution suggests multiple explosion locations, as well as unstable or directed jets, affected by the initially formed crater walls (Taddeucci et al. 2013; Graettinger et al. 2015). In particular, the large abundance of OI material with low impact angle (Fig. 4a-f), and the large deposit thickness to the north, point to multiple shallow explosions at later stages of the eruption 


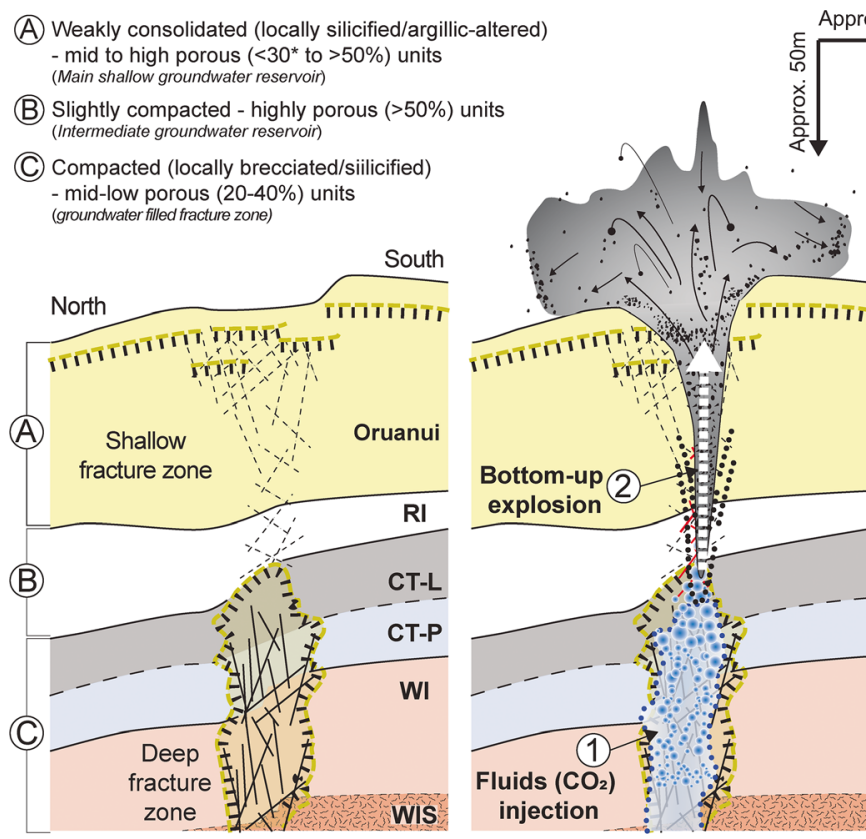

Fig. 10 Conceptual cartoon (not to scale) showing the geological setting and the evolution of the Champagne Pool eruption. A rapid pulse of heat and gas pressure from magmatic fluids $\left(\mathrm{CO}_{2}\right)$ was focused into preexisting faults and fractures (1), to overpressure geothermal fluids until aquitards were disrupted (2), and rapid fluid decompression began (3). The breaking of harder/low porosity host rocks at depth led to a first narrow/localised bottom-up explosions, eventually only breaking to the surface with low energy and emplaced a small breccia deposit (brown lower bed). The second phase, much more extensive, produced wider

that migrated/excavated northward (Valentine et al. 2015; Kennedy et al. 2020; Montanaro et al. 2020).

Geothermal features such as hot-spring conduits, hydrothermal eruption vents, and collapsed craters, are most commonly found close to faults (Curewitz and Karson 1997; Rowland and Simmons 2012; D'Elia et al. 2020). Structural features can also control vent migration during explosive events involving fluids rising through fractures (Ort and Carrasco-Núñez 2009). A local graben contains the collapsed craters and the Champagne Pool and creates a morphological buttress on the west and south sides of the pool. A SSW-NNEstriking fracture cuts through the crater site (Fig. 1; Lloyd 1959; Curewitz and Karson 1997). These all indicate a fracture-controlled migration of the explosion loci, especially during its later eruption stages (Jordan et al. 2013; LópezRojas and Carrasco-Núñez 2015; Graettinger 2018).

Combining the structural and breccia features, we suggest that the initial deep-sourced jet occurred in the southern part of the crater area, and was followed by a decompression/flashing front propagating northward through the OI-hosted shallow reservoir (Fig. 10). Continuous flashing of fluids likely fuelled shallow explosions and subsequently enlarged the crater. A similar mechanism is described for the formation of craters at Lake Okaro and Whakaari/White Island (Kennedy et al. 2020; Montanaro et al. 2020). Slumping of shallow unconsolidated

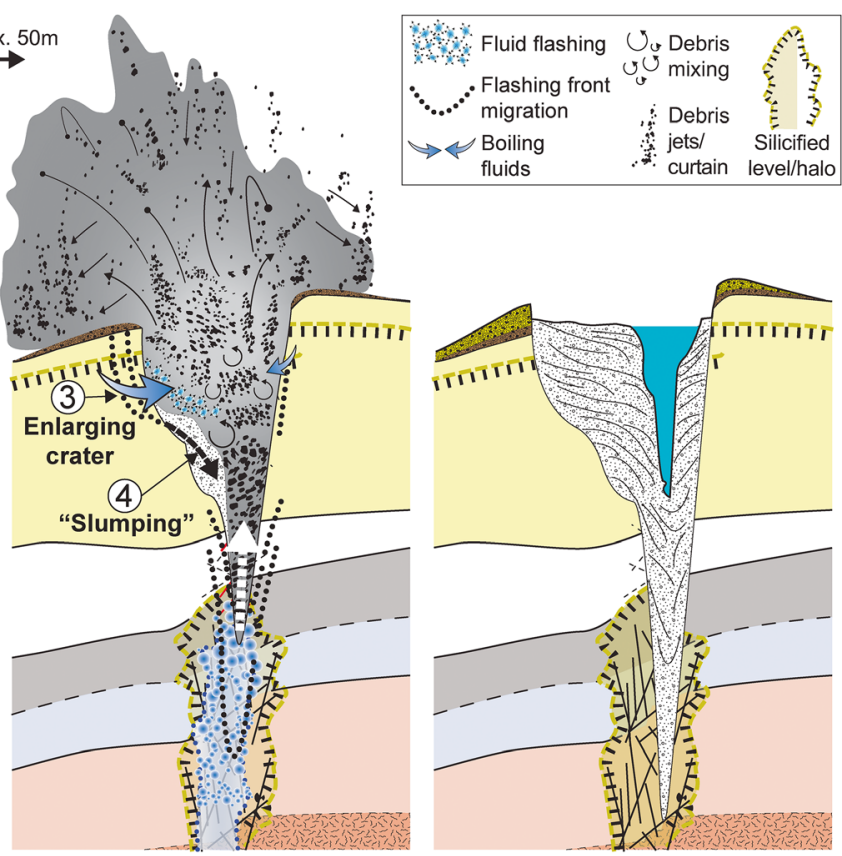

ejection of larger particles and a final thicker breccia (yellow upper bed). This occurred when weak/unconsolidated and highly porous units near the surface were disrupted. The transition between the two phases of eruption occurred when deeper eruptions broke through silicified and stronger aquitard layers. The soft substrate disrupted during the second phase collapsed into the crater centre to repeatedly choke and induce ongoing deeper-sourced eruptions while also spreading laterally along a local fault strike (3-4). Final collapse of the crater rim material lent the crater its final shape

deposits into the central vent area likely intermittently blocked it, inducing further deep explosions and sporadic debris jets transporting deeper clasts into the shallow ejection zone (cf., Sweeney and Valentine 2015). This, along with recycling of the lower breccia bed during crater widening, explains the deeply sourced fragments in the OI-dominated upper breccia bed. The presence of argillic-altered layers within the base of the OI deposit (Hedenquist and Henley 1985) could have also contributed to slumping/collapse during the northward excavation (Fig. 10). The breccia distribution pattern may also reflect strongly asymmetrical jets (cf., Graettinger et al. 2015). Once the eruption ended, collapse and compaction of the material occurred in the northern basin (Fig. 10). This suggests that the final size of the crater produced by the eruption itself was approximately 100-120 m (Fig. 1b).

\section{Eruption dynamics and energetic considerations}

Here, we compare the Champagne Pool eruption to studies of natural explosion craters (Yokoo et al. 2002; Valentine et al. 2015; Montanaro et al. 2016; Graettinger and Valentine 2017; D'Elia et al. 2020), and field-based explosion experiments (Goto et al. 2001; Ohba et al. 2002; Taddeucci et al. 2013; Graettinger et al. 2014; Sonder et al. 2015; Macorps et al. 2016). The experiments show that eruption dynamics and 
emplacement of ejecta depend strongly on the combination of explosion depth and energy, and the local topography. The relationship between energy and depth of explosion can be characterised by the scaled depth (physical depth divided by the cube root of energy; Goto et al. 2001). The scaled-depth condition during which the largest craters are produced is $\sim 0.004 \mathrm{~m} / \mathrm{J}^{1 / 3}$. At scaled depths of $\sim 0.008 \mathrm{~m} / \mathrm{J}^{1 / 3}$ and greater, explosion energy is predominantly confined below ground, with no ejecta (Valentine et al. 2014). However, if deepseated fragments are incrementally transported upward by explosions to optimal depths (Ross and White 2006; Sweeney and Valentine 2015), they may be eventually transported to the surface. If we assume that the largest crater produced during the initial Champagne Pool eruption was $\sim 60 \mathrm{~m}$ in diameter (the current pool dimension), the Goto et al. (2001) relationship would suggest an explosive energy of $\sim 10^{12} \mathrm{~J}$. This value is likely an order of magnitude too low, since it does not include the energy loss to fragmentation (AlatorreIbargüengoitia et al. 2010; Montanaro et al. 2016). Neither does it include the effect of explosivity-enhancing gases (e.g. $\mathrm{CO}_{2}$; Thiéry et al. 2010; Hurwitz et al. 2016) or steamflashing of heated groundwater (Mastin 1995; Thiéry and Mercury 2009; Montanaro et al. 2016). Thus, an explosive energy of $\sim 10^{13} \mathrm{~J}$ is more likely, corresponding to an optimal scaled depth between 86 and $93 \mathrm{~m}$, and a confinement depth between 172 and $187 \mathrm{~m}$ (Sonder et al. 2015).

The lower breccia bed is a massive deposit with abundant blocks sourced from different stratigraphic levels, including clasts of the 100-110-m-deep CT-P, which is well within the scaled conditions suggested above. The upper breccia is thicker, wider spread, and associated with numerous larger blocks within proximal and medial facies. These clasts are dominated by material excavated from the OI unit $(\sim 80$ $70 \mathrm{~m}$ ). The texture, componentry, and explosion depth estimated for both breccias imply a deposition from ballistic curtains, with extremely rapid sedimentation from a spreading and collapsing jet (Fig. 10; Graettinger et al. 2015; Graettinger and Valentine 2017).

Theoretical considerations and experimental results reveal an increasing explosive energy with porosity, suggesting that reservoirs hosted within the shallow RI and OI $(<100 \mathrm{~m})$ had a higher explosive potential (17 to $\left.\sim 21 \mathrm{MJ} / \mathrm{m}^{3}\right)$ than deepseated $(>100 \mathrm{~m})$ reservoirs $\left(\sim 8\right.$ to $\left.\sim 16 \mathrm{MJ} / \mathrm{m}^{3}\right)$ within CT$\mathrm{P} / \mathrm{L}$ and WI/WIS (Fig. 6a). The exploded host rock lithologies also modulated the fragmentation and ejection behaviour (Scheu et al. 2006). In this, alteration-driven changes in host rock properties must be considered. Secondary mineralisation can reduce matrix permeability, especially formation of expanded hydrated minerals (clays) and silica precipitation within pores and veins (Dobson et al. 2003; Heap et al. 2019, 2020). Porosity reduction results reduce the content of hot and pressurised fluids, ultimately reducing the fragmentation efficiency (Mayer et al. 2016; Montanaro et al. 2016, c). In our study, weaker explosivity is indicated by the coarser median grain size and lower weight $\%$ of fine ash $(3 \phi)$ in experiments (Fig. 6b, c). In addition, silica-strengthening of lithologies affected the fragmentation speed, which does not show the expected positive correlation with explosive energies (Mayer et al. 2016; Montanaro et al. 2016). For the estimated energies, rocks with porosity $<32 \%$ are only partially fragmented (Fig. 6). Among the rocks with higher porosities, the relatively more cohesive/compacted lithologies (which are also generally deeper in this case) show comparatively low production of fines $(\sim 1-18 \mathrm{wt} \%$ vs. $\sim 12-33.9 \mathrm{wt} \%)$, as well as lower ejection $(196 \pm 16 \mathrm{~m} / \mathrm{s}$ vs. $216 \pm 13 \mathrm{~m} / \mathrm{s})$ and fragmentation velocities $(158 \pm 6 \mathrm{~m} / \mathrm{s}$ vs. $166 \pm 9 \mathrm{~m} / \mathrm{s})$ than the shallow, weakly silicified units (Figs. 6c and 8a, b). The higher fragmentation velocity and the greater fines generation of the weakly consolidated OI compared with the firmer RI further highlights the effect of rock strength on eruption style (Haug et al. 2013; Montanaro et al. 2016). Experimental results and field interpretation indicate that the deeper lithologies require higher energy to be fragmented and ejected, whereas fragmenting/ disaggregating the OI and enlarging a crater requires less energy (Morgan et al. 2009; Alatorre-Ibargüengoitia et al. 2010; Galland et al. 2014; Montanaro et al. 2016, 2020). The soft OI lithology, combined with shallow explosions, produced large volumes of ejecta (Graettinger et al. 2015), that were mostly dispersed to the north (Figs. 1b and 10).

The lateral extent of a ballistic curtain deposit also depends upon the explosion energy and on its scaled depth (Graettinger et al. 2015). Although exposure is limited, both the lower and upper breccia bed have high aspect ratios, with thick deposits near the crater, and rapid thinning away from it. The lower bed contains fewer and smaller blocks than the upper bed, the latter including $>50$-cm-diameter blocks launched over $200 \mathrm{~m}$ from the crater. Thus, if the two beds were sourced from explosions below the main Champagne Pool crater, the upper breccia must have resulted from higher energy conversion into kinetic energy. Experimental data show that deepsourced lithologies (e.g. CT-P/L) produce low ejection velocities, compared with OI and RI. Also, the Champagne Pool eruption likely produced a dense particle-rich jet, so that the friction within the mixture, and between the erupting material and the conduit walls, reduces the kinetic energy (Mastin 1995). This friction loss may have been most important during deep-sourced explosions (Fig. 10).

\section{Conclusions}

Host rock properties of geothermal systems strongly affect cratering processes, eruption style, and related hazards during steam-driven hydrothermal eruptions (Mastin 1995; Browne and Lawless 2001; Haug et al. 2013; Montanaro et al. 2016, 2020; Heap et al. 2020; Kennedy et al. 2020). Analysis of the 
Champagne Pool breccia and drill core materials, along with decompression experiments, allowed us to fingerprint the eruption source depth and fluid state during all phases of the eruption. Stratigraphic boundaries, along with variable degrees of alteration affecting porosity, and host rock strength played a key role in eruption dynamics. Heat and gas pressure from magma below was focused into pre-existing faults and fractures, to overpressure geothermal fluids until aquitards were disrupted and rapid fluid decompression began. The geometry of the deposits with harder, low porosity units at depth led to the first narrow/localised explosions, initially only breaking to the surface with low ejection energy. The second phase was laterally much more extensive and, overall, more violent at the surface, with wider ejection of larger particles and formation of thicker deposits. This occurred when shallow weak/unconsolidated and highly porous units were disrupted. The transition between the two eruption phases occurred when deeper eruptions broke through a silicified, strong aquitard layer. The contrasting rock properties remain reflected in the champagne-glass-like geometry of Champagne Pool.

Investigations of similar eruptions under different geological conditions should be undertaken to widen our understanding of how local host lithologies and associated hydrological conditions affect priming/triggering mechanisms, eruption dynamics, crater size, and deposition mechanisms. From this study, we suggest that if predominantly soft, unconsolidated, and highly porous strata are disrupted during hydrothermal eruptions, broad and irregular craters will form. Crater shapes may reflect also concentrated decompression and fluid expansion along rift or fracture orientations. Eruptions in soft substrates may be highly irregular, with repeated blocking and explosive clearance of central deeper vents by repeated slumping of crater walls. By contrast, hydrothermal eruptions within harder, less porous material, may cause narrower, deeper craters, with a greater tendency to focus fluids expansion into smaller, localised areas. Consequently, these may also produce more localised deposits from lower-intensity debris jetting and a more rapid caseation of eruption as pressure equilibrates because crater walls are stable.

Substrate/host rock settings play a key role in hazard intensity metrics of hydrothermal eruptions, which are fundamental for impact assessment and planning. It is apparent that both parent geology and alteration-induced lithological changes (e.g. silicification) are important for generating a depthvariability of host rock properties (e.g. porosity and rock strength) that strongly influence the dynamics and spatial impact of hydrothermal eruptions. By understanding the local geology, geothermal alteration properties, and hydrology of active geothermal areas in active tectonic settings, first-order eruption scenarios can be proposed for different geological and geometric settings across susceptible areas, taking into account pre-existing faults and other structural features that focus fluid flow from below.
Acknowledgements A.G., C.M., and S.C. acknowledge funding from the New Zealand Ministry of Business, Innovation and Employment Smart Ideas grant "Stable power generation and tourism with reduced geothermal explosion hazard, UOAX1807". C.M. was also supported by the Deutsche Forschungsgemeinschaft under grant MO3508/1-1. D.B.D. acknowledges support of ERC-2018-ADV Grant 834225 (EAVESDROP). We also acknowledge the Ngati Tahu-Ngati Whaoa Runanga Trust, as the landowner and mana whenua of the Wai-o-Tapu Scenic Reserve, and thank the Trust (particularly Johlene Kelly), Wai-oTapu Thermal Wonderland, and New Zealand Department of Conservation (Te Papa Atawhai) who supported this research. We thank Dr. Alison Graettinger, an anonymous reviewer, associate editor Dr. Gert Lube, and executive editor Andrew Harris for comments that helped refine this manuscript.

Author contributions A.G. and C.M. led the project and wrote the manuscript draft. Fieldwork and sample collection were carried out by A.G., C.M., and S.C.. A.G. and C.M. performed the laboratory measurements of porosity, density, and P-wave velocities with help from B.S.. A.G. and C.M. also performed the decompression experiments, grain size, and video analyses. A.G. and C.M. performed the thermodynamics calculations. All authors contributed to the writing of the manuscript.

Funding Open Access funding enabled and organized by Projekt DEAL.

\section{Compliance with ethical standards}

Competing interests The authors declare that they have no competing interests.

Open Access This article is licensed under a Creative Commons Attribution 4.0 International License, which permits use, sharing, adaptation, distribution and reproduction in any medium or format, as long as you give appropriate credit to the original author(s) and the source, provide a link to the Creative Commons licence, and indicate if changes were made. The images or other third party material in this article are included in the article's Creative Commons licence, unless indicated otherwise in a credit line to the material. If material is not included in the article's Creative Commons licence and your intended use is not permitted by statutory regulation or exceeds the permitted use, you will need to obtain permission directly from the copyright holder. To view a copy of this licence, visit http://creativecommons.org/licenses/by/4.0/.

\section{References}

Alatorre-Ibargüengoitia MA, Scheu B, Dingwell DB et al (2010) Energy consumption by magmatic fragmentation and pyroclast ejection during Vulcanian eruptions. Earth Planet Sci Lett 291:60-69. https:// doi.org/10.1016/j.epsl.2009.12.051

Bibby H, Bennie S, Stagpoole V, Caldwell T (1994) Resistivity structure of the Waimangu, Waiotapu, Waikite and Reporoa geothermal areas, New Zealand. Geothermics 23:445-471. https://doi.org/10. 1016/0375-6505(94)90013-2

Breard ECP, Lube G, Cronin SJ, Fitzgerald R, Kennedy B, Scheu B, Montanaro C, White JDL, Tost M, Procter JN, Moebis A (2014) Using the spatial distribution and lithology of ballistic blocks to interpret eruption sequence and dynamics: August 62012 Upper Te Maari eruption, New Zealand. J Volcanol Geotherm Res 286: 373-386. https://doi.org/10.1016/j.jvolgeores.2014.03.006

Bromley CJ, Mongillo MA (1994) Hydrothermal eruptions - a hazard assessment. In: Proceedings 16th NZ Geothermal Workshop 
Browne PRL, Lawless JV (2001) Characteristics of hydrothermal eruptions, with examples from New Zealand and elsewhere. Earth Sci Rev 52:299-331. https://doi.org/10.1016/S0012-8252(00)00030-1

Carlino S, Piochi M, Tramelli A, Mormone A, Montanaro C, Scheu B, Klaus M (2018) Field-scale permeability and temperature of volcanic crust from borehole data: Campi Flegrei, southern Italy. J Volcanol Geotherm Res 357:276-286. https://doi.org/10.1016/j. jvolgeores.2018.05.003

Christenson BW, Reyes AG, Young R et al (2010) Cyclic processes and factors leading to phreatic eruption events: insights from the 25 September 2007 eruption through Ruapehu crater Lake, New Zealand. J Volcanol Geotherm Res 191:15-32. https://doi.org/10. 1016/j.jvolgeores.2010.01.008

Curewitz D, Karson JA (1997) Structural settings of hydrothermal outflow: fracture permeability maintained by fault propagation and interaction. J Volcanol Geotherm Res 79:149-168. https://doi.org/10. 1016/S0377-0273(97)00027-9

D’Elia L, Páez G, Hernando IR et al (2020) Hydrothermal eruptions at El Humazo, Domuyo geothermal field, Argentina: insights into the eruptive dynamics and controls. J Volcanol Geotherm Res 393: 106786. https://doi.org/10.1016/j.jvolgeores.2020.106786

Dempsey DE, Rowland JV, Zyvoloski GA, Archer RA (2012) Modeling the effects of silica deposition and fault rupture on natural geothermal systems. J Geophys Res Solid Earth 117:1-18. https://doi.org/ 10.1029/2012JB009218

Dench ND (1963) Investigations for geothermal power at Waiotapu, New Zealand. In: Proceedings of the United Nations Conference on New Sources of Energy: Solar Energy, Wind Power and Geothermal Energy pp 179-193

Dobson PF, Kneafsey TJ, Hulen J, Simmons A (2003) Porosity, permeability, and fluid flow in the Yellowstone geothermal system, Wyoming. J Volcanol Geotherm Res 123:313-324. https://doi.org/ 10.1016/S0377-0273(03)00039-8

Galland O, Gisler GR, Haug OT (2014) Morphology and dynamics of explosive vents through cohesive rock formations. J Geophys Res Solid Earth 119:4708-4728. https://doi.org/10.1002/2014JB011050

Germanovich LN, Lowell RP (1995) The mechanism of phreatic eruptions. J Geophys Res Solid Earth 100:8417-8434

Geshi N, Németh K, Oikawa T (2011) Growth of phreatomagmatic explosion craters: a model inferred from Suoana crater in Miyakejima Volcano, Japan. J Volcanol Geotherm Res 201:30-38. https:/doi. org/10.1016/j.jvolgeores.2010.11.012

Goto A, Taniguchi H, Yoshida M, Ohba T, Oshima H (2001) Effects of explosion energy and depth to the formation of blast wave and crater: field explosion experiment for the understanding of volcanic explosion. Geophys Res Lett 28:4287-4290. https://doi.org/10. 1029/2001GL013213

Graettinger AH (2018) Trends in maar crater size and shape using the global Maar Volcano Location and Shape (MaarVLS) database. J Volcanol Geotherm Res 357:1-13. https://doi.org/10.1016/j. jvolgeores.2018.04.002

Graettinger AH, Valentine GA (2017) Evidence for the relative depths and energies of phreatomagmatic explosions recorded in tephra rings. Bull Volcanol 79:88. https://doi.org/10.1007/s00445-017$1177-\mathrm{x}$

Graettinger AH, Valentine GA, Sonder I (2015) Circum-crater variability of deposits from discrete, laterally and vertically migrating volcanic explosions: experimental evidence and field implications. J Volcanol Geotherm Res 308:61-69. https://doi.org/10.1016/j. jvolgeores.2015.10.019

Graettinger AH, Valentine G, a., Sonder I, et al (2014) Maar-diatreme geometry and deposits: Subsurface blast experiments with variable explosion depth. Geochem Geophys Geosyst 15:740-764. https:// doi.org/10.1002/2013GC005198

Graettinger AH, Valentine GA, Sonder I et al (2015) Facies distribution of ejecta in analog tephra rings from experiments with single and multiple subsurface explosions. Bull Volcanol 77:66. https://doi. org/10.1007/s00445-015-0951-x

Haug ØT, Galland O, Gisler GR (2013) Experimental modelling of fragmentation applied to volcanic explosions. Earth Planet Sci Lett 384: 188-197. https://doi.org/10.1016/j.epsl.2013.10.004

Heap MJ, Gravley DM, Kennedy BM, Gilg HA, Bertolett E, Barker SLL (2020) Quantifying the role of hydrothermal alteration in creating geothermal and epithermal mineral resources: the Ohakuri ignimbrite (Taupō Volcanic Zone, New Zealand). J Volcanol Geotherm Res 390:106703. https://doi.org/10.1016/j.jvolgeores.2019.106703

Heap MJ, Kennedy BM, Farquharson JI, Ashworth J, Mayer K, LethamBrake M, Reuschlé T, Gilg HA, Scheu B, Lavallée Y, Siratovich P, Cole J, Jolly AD, Baud P, Dingwell DB (2017) A multidisciplinary approach to quantify the permeability of the Whakaari/White Island volcanic hydrothermal system (Taupo Volcanic Zone, New Zealand). J Volcanol Geotherm Res 332:88-108

Heap MJ, Troll VR, Kushnir ARL, Gilg HA, Collinson ASD, Deegan FM, Darmawan H, Seraphine N, Neuberg J, Walter TR (2019) Hydrothermal alteration of andesitic lava domes can lead to explosive volcanic behaviour. Nat Commun 10:1-10. https://doi.org/10. 1038/s41467-019-13102-8

Hedenquist JW (1991) Boiling and dilution in the shallow portion of the Waiotapu geothermal system, New Zealand. Geochim Cosmochim Acta 55:2753-2765. https://doi.org/10.1016/0016-7037(91)904428

Hedenquist JW, Browne PRL (1989) The evolution of the Waiotapu geothermal system, New Zealand, based on the chemical and isotopic composition of its fluids, minerals and rocks. Geochim Cosmochim Acta 53:2235-2251

Hedenquist JW, Henley RW (1985) Hydrothermal eruptions in the Waiotapu geothermal system, New Zealand: their origin, associated breccias, and relation to precious metal mineralization. Econ Geol 80:1640-1668. https://doi.org/10.2113/gsecongeo.80.6.1640

Hurwitz S, Clor LE, McCleskey RB et al (2016) Dissolved gases in hydrothermal (phreatic) and geyser eruptions at Yellowstone National Park, USA. Geology 44:G37478.1. https://doi.org/10. 1130/G37478.1

Jolly A, Caudron C, Girona T et al (2020) 'Silent' dome emplacement into a wet volcano : observations from an effusive eruption at White Island ( Whakaari ), New Zealand in late 2012. Geosciences 142:113

Jordan SC, Cas RAF, Hayman PC (2013) The origin of a large ( $>3 \mathrm{~km})$ maar volcano by coalescence of multiple shallow craters: Lake Purrumbete maar, southeastern Australia. J Volcanol Geotherm Res 254:5-22. https://doi.org/10.1016/j.jvolgeores.2012.12.019

Kennedy BM, Farquhar A, Hilderman R, Villeneuve MC, Heap MJ, Mordensky S, Kilgour G, Jolly A, Christenson B, Reuschlé T (2020) Pressure controlled permeability in a conduit filled with fractured hydrothermal breccia reconstructed from ballistics from Whakaari ( White Island ), New Zealand. Geosciences 10:1-19. https://doi.org/10.3390/geosciences10040138

Kilgour G, Gates S, Kennedy B, Farquhar A, McSporran A, Asher C (2019) Phreatic eruption dynamics derived from deposit analysis: a case study from a small, phreatic eruption from Whakāri/White Island, New Zealand. Earth, Planets Space 71:21. https://doi.org/10. 1186/s40623-019-1008-8

Krupp RE, Seward TM (1987) The Rotokawa Geothermal System, New Zealand: an active epithermal gold-depositing environment. Econ Geol 4:1109-1129

Kueppers U, Scheu B, Spieler O, Dingwell DB (2006) Fragmentation efficiency of explosive volcanic eruptions: a study of experimentally generated pyroclasts. J Volcanol Geotherm Res 153:125-135. https://doi.org/10.1016/j.jvolgeores.2005.08.006

Leonard GS, Begg JG, Wilson CJJ (2010) Geology of the Rotorua area. Institute of Geological and Nuclear Sciences (GNS) 
Lloyd EF (1959) The hot springs and hydrothermal eruptions of Waiotapu. N Z J Geol Geophys 2:141-176. https://doi.org/10. 1080/00288306.1959.10431319

López-Rojas M, Carrasco-Núñez G (2015) Depositional facies and migration of the eruptive loci for Atexcac axalapazco (central Mexico): implications for the morphology of the crater. Rev Mex Cienc Geol 32:377-394

Lowell RP, Van Cappellen P, Germanovich LN (1993) Silica precipitation in fractures and the evolution of permeability in hydrothermal upflow zones. Science (80- ) 260:192-194. https://doi.org/10.1126/ science.260.5105.192

Lube G, Breard ECP, Cronin SJ et al (2014) Dynamics of surges generated by hydrothermal blasts during the 6 August 2012 Te Maari eruption, Mt. Tongariro, New Zealand. J Volcanol Geotherm Res. https://doi.org/10.1016/j.jvolgeores.2014.05.010

Macorps É, Graettinger AH, Valentine GA, Ross PS, White JDL, Sonder I (2016) The effects of the host-substrate properties on maardiatreme volcanoes: experimental evidence. Bull Volcanol 78:112. https://doi.org/10.1007/s00445-016-1013-8

Maeno F, Nakada S, Nagai M, Kozono T (2013) Ballistic ejecta and eruption condition of the vulcanian explosion of Shinmoedake volcano, Kyushu, Japan on 1 February, 2011. Earth, Planets Space 65: 609-621. https://doi.org/10.5047/eps.2013.03.004

Maeno F, Nakada S, Oikawa T et al (2016) Reconstruction of a phreatic eruption on 27 September 2014 at Ontake volcano, central Japan, based on proximal pyroclastic density current and fallout deposits. Earth, Planets Sp 68:1. https://doi.org/10.1186/s40623-016-0449-6

Mastin LG (1995) Thermodynamics of gas and steam-blast eruptions. Bull Volcanol 57:85-98. https://doi.org/10.1007/BF00301399

Mayer K, Scheu B, Gilg HA, Heap MJ, Kennedy BM, Lavallée Y, Letham-Brake M, Dingwell DB (2015) Experimental constraints on phreatic eruption processes at Whakaari (White Island volcano). J Volcanol Geotherm Res 302:150-162. https://doi.org/10.1016/j. jvolgeores.2015.06.014

Mayer K, Scheu B, Montanaro C, Yilmaz TI, Isaia R, Aßbichler D, Dingwell DB (2016) Hydrothermal alteration of surficial rocks at Solfatara (Campi Flegrei): petrophysical properties and implications for phreatic eruption processes. J Volcanol Geotherm Res 320:128 143. https://doi.org/10.1016/j.jvolgeores.2016.04.020

Mielke P, Prieto A, Bignall G, Sass I (2015) Effect of hydrothermal alteration on rock properties in the Tauhara Geothermal Field, New Zealand. In: Proc World Geothermal Congress 2015

Milicich SD, Chambefort I, Wilson CJN, Alcaraz S, Ireland TR, Bardsley C, Simpson MP (2020) A zircon U-Pb geochronology for the Rotokawa geothermal system, New Zealand, with implications for Taupō Volcanic Zone evolution. J Volcanol Geotherm Res 389: 106729. https://doi.org/10.1016/j.jvolgeores.2019.106729

Milicich SD, Clark JP, Wong C, Askari M (2016) A review of the Kawerau Geothermal Field, New Zealand. Geothermics 59:252265. https://doi.org/10.1016/j.geothermics.2015.06.012

Montanaro C, Cronin S, Scheu B, Kennedy B, Scott B (2020) Complex crater fields formed by steam-driven eruptions: Lake Okaro, New Zealand. GSA Bull 132:1914-1930. https://doi.org/10.1130/ b35276.1

Montanaro C, Scheu B, Cronin SJ, Breard ECP, Lube G, Dingwell DB (2016) Experimental estimates of the energy budget of hydrothermal eruptions; application to 2012 Upper Te Maari eruption, New Zealand. Earth Planet Sci Lett 452:281-294. https://doi.org/10. 1016/j.epsl.2016.07.052

Montanaro C, Scheu B, Gudmundsson MT, Vogfjörd K, Reynolds HI, Dürig T, Strehlow K, Rott S, Reuschlé T, Dingwell DB (2016) Multidisciplinary constraints of hydrothermal explosions based on the 2013 Gengissig lake events, Kverkfjöll volcano, Iceland. Earth Planet Sci Lett 434:308-319. https://doi.org/10.1016/j.eps1.2015.11. 043
Montanaro C, Scheu B, Mayer K, Orsi G, Moretti R, Isaia R, Dingwell DB (2016) Experimental investigations on the explosivity of steamdriven eruptions: a case study of Solfatara volcano (Campi Flegrei). J Geophys Res Solid Earth 121:7996-8014. https://doi.org/10.1002/ 2016JB013273

Morgan LA, Shanks WCP, Pierce KL (2009) Hydrothermal processes above the Yellowstone magma chamber: Large hydrothermal systems and large hydrothermal explosions. Geological Society of America Special Paper

Nairn IA, Hedenquist JW, Villamor P, Berryman KR, Shane PA (2005) The $\sim$ AD1315 Tarawera and Waiotapu eruptions, New Zealand: contemporaneous rhyolite and hydrothermal eruptions driven by an arrested basalt dike system? Bull Volcanol 67:186-193. https:// doi.org/10.1007/s00445-004-0373-7

Nairn IA, Wiradiradja S (1980) Late quaternary hydrothermal explosion breccias at Kawerau Geothermal Field, New Zealand. Bull Volcanol 43:1-13. https://doi.org/10.1007/BF02597607

Nairn IA, Wood CP, Bailey RA (1994) The Reporoa caldera, Taupo Volcanic Zone: source of the Kaingaroa ignimbrites. Bull Volcanol 56:529-537. https://doi.org/10.1007/BF00302833

Ohba T, Taniguchi H, Oshima H, Yoshida M, Goto A (2002) Effect of explosion energy and depth on the nature of explosion cloud a field experimental study. J Volcanol Geotherm Res 115:33-42. https:// doi.org/10.1016/S0377-0273(01)00307-9

Ort MH, Carrasco-Núñez G (2009) Lateral vent migration during phreatomagmatic and magmatic eruptions at Tecuitlapa Maar, east-central Mexico. J Volcanol Geotherm Res 181:67-77. https:// doi.org/10.1016/j.jvolgeores.2009.01.003

Phillips WJ (1979) Hydraulic fracturing and mineralization. Geol Soc London 128:337-359. https://doi.org/10.1144/gsjgs.128.4.0337

Pittari A, Briggs RM, Bowyer DA (2016) Subsurface geology, ancient hydrothermal systems and crater excavation processes beneath Lake Rotomahana: evidence from lithic clasts of the $1886 \mathrm{AD}$ Rotomahana Pyroclastics. J Volcanol Geotherm Res 314:110-125. https://doi.org/10.1016/j.jvolgeores.2015.10.009

Rosi M, Di Traglia F, Pistolesi M et al (2018) Dynamics of shallow hydrothermal eruptions: new insights from Vulcano' s Breccia di Commenda eruption. Bull Volcanol 80:28

Ross PS, White JDL (2006) Debris jets in continental phreatomagmatic volcanoes: a field study of their subterranean deposits in the Coombs Hills vent complex, Antarctica. J Volcanol Geotherm Res 149:6284. https://doi.org/10.1016/j.jvolgeores.2005.06.007

Rowland JV, Simmons SF (2012) Hydrologic, magmatic, and tectonic controls on hydrothermal flow, Taupo Volcanic Zone, New Zealand: implications for the formation of epithermal vein deposits. Econ Geol 107:427-457. https://doi.org/10.2113/econgeo.107.3. 427

Scheu B, Kueppers U, Mueller S, Spieler O, Dingwell DB (2008) Experimental volcanology on eruptive products of Unzen volcano. J Volcanol Geotherm Res 175:110-119. https://doi.org/10.1016/j. jvolgeores.2008.03.023

Scheu B, Spieler O, Dingwell DB (2006) Dynamics of explosive volcanism at Unzen volcano: an experimental contribution. Bull Volcanol 69:175-187. https://doi.org/10.1007/s00445-006-0066-5

Sonder I, Graettinger AH, Valentine GA (2015) Scaling multiblast craters: general approach and application. J Geophys Res Solid Earth 120:6141-6158. https://doi.org/10.1002/2015JB012018.Abstract

Stearns HA, McDonald GA (1949) Geology and groundwater resources of the island of Hawaii. Hawaii Div Hydrogr Bull 9:1-363

Stix J, De Moor JM (2018) Understanding and forecasting phreatic eruptions driven by magmatic degassing. Earth, Planets Space 70:19. https://doi.org/10.1186/s40623-018-0855-z

Sweeney MR, Valentine GA (2015) Transport and mixing dynamics from explosions in debris-filled volcanic conduits: numerical results and implications for maar-diatreme volcanoes. Earth Planet Sci Lett 425:64-76. https://doi.org/10.1016/j.eps1.2015.05.038 
Taddeucci J, Valentine GA, Sonder I et al (2013) The effect of preexisting craters on the initial development of explosive volcanic eruptions: an experimental investigation. Geophys Res Lett 40: 507-510. https://doi.org/10.1002/grl.50176

Thiéry R, Loock S, Mercury L (2010) Explosive properties of superheated aqueous solutions in volcanic and hydrothermal systems. In: Rzoska S, Drozd-Rzoska A, Mazur V (eds) Metastable systems under pressure, NATO Scien. Springer, Dordrecht, pp 293-310

Thiéry R, Mercury L (2009) Explosive properties of water in volcanic and hydrothermal systems. J Geophys Res Solid Earth 114:1-19. https:// doi.org/10.1029/2008JB005742

Uysal IT, Feng YX, Zhao JX, Isik V, Nuriel P, Golding SD (2009) Hydrothermal CO2 degassing in seismically active zones during the late Quaternary. Chem Geol 265:442-454. https://doi.org/10. 1016/j.chemgeo.2009.05.011

Valentine GA, Graettinger AH, Macorps É, Ross PS, White JDL, Döhring E, Sonder I (2015) Experiments with vertically and laterally migrating subsurface explosions with applications to the geology of phreatomagmatic and hydrothermal explosion craters and diatremes. Bull Volcanol 77. https://doi.org/10.1007/s00445-015-0901-7

Valentine GA, Graettinger AH, Sonder I (2014) Explosion depths for phreatomagmatic eruptions. Geophys Res Lett 41:3045-3051. https://doi.org/10.1002/2014GL060096

Valentine GA, Sottili G, Palladino DM, Taddeucci J (2015) Tephra ring interpretation in light of evolving maar-diatreme concepts:
Stracciacappa maar (central Italy). J Volcanol Geotherm Res 308: 19-29. https://doi.org/10.1016/j.jvolgeores.2015.10.010

Van Eaton AR, Wilson CJN (2013) The nature, origins and distribution of ash aggregates in a large-scale wet eruption deposit: Oruanui, New Zealand. J Volcanol Geotherm Res 250:129-154. https://doi. org/10.1016/j.jvolgeores.2012.10.016

White DE, Fournier R, Muffler LJP, Truesdell AH (1975) Physical results of research drilling in thermal areas of Yellowstone National Park, Wyoming. Geol Surv Prof Pap 892:69. https://doi.org/10.3133/ pp892

Wilson CJN, Charlier BLA, Rowland JV, Browne PRL (2010) U-Pb dating of zircon in subsurface, hydrothermally altered pyroclastic deposits and implications for subsidence in a magmatically active rift: Taupo volcanic zone, New Zealand. J Volcanol Geotherm Res 191:69-78. https://doi.org/10.1016/j.jvolgeores.2010.01.001

Wilson CJN, Rowland JV (2016) The volcanic, magmatic and tectonic setting of the Taupo Volcanic Zone, New Zealand, reviewed from a geothermal perspective. Geothermics 59:168-187. https://doi.org/ 10.1016/j.geothermics.2015.06.013

Yamamoto T (2014) The pyroclastic density currents generated by the September 27, 2014 phreatic eruption of Ontake Volcano, Japan. Bull Geol Surv Japan 65:117-127

Yokoo A, Goto A, Taniguchi H, Oshima H (2002) Energy and depth of Usu 2000 phreatic explosions. Geophys Res Lett 29:48-51. https:// doi.org/10.1029/2002GL015928 